\title{
A unique Pyrenean varved record provides a detailed reconstruction of Mediterranean vegetation and land-use dynamics over the last three millennia
}

\author{
Valentí Rull $^{\text {a, * }}$, Teresa Vegas-Vilarrúbia ${ }^{\text {b }}$, Juan Pablo Corella ${ }^{c}$, Mari C. Trapote ${ }^{\text {b, d }}$, \\ Encarni Montoya ${ }^{\mathrm{e}}$, Blas Valero-Garcés ${ }^{\mathrm{f}}$ \\ ${ }^{a}$ Botanic Institute of Barcelona (CSIC), Pg. Del Migdia S/n, 08038, Barcelona, Spain \\ ${ }^{\mathrm{b}}$ Department of Evolutionary Biology, Ecology and Environmental Sciences, University of Barcelona, Av. Diagonal 645, 08028, Barcelona, Spain \\ ' CIEMAT, Environmental Department, Av. Complutense 40, 28040, Madrid, Spain \\ d DBO5 SL, Polígono Pisa, C. Artesanía 23 2F, 41927, Mairena de Aljarafe, Sevilla, Spain \\ e Department of Geography and Planning, University of Liverpool, Liverpool, L69 7ZT, UK \\ ${ }^{\mathrm{f}}$ Pyrenean Institute of Ecology (CSIC), Av. Montañana 1005C, 50059, Zaragoza, Spain
}

\section{A R T I C L E I N F O}

\section{Article history:}

Received 31 May 2021

Received in revised form

28 July 2021

Accepted 28 July 2021

Available online 13 August 2021

Handling Editor: Donatella Magri

\section{Keywords:}

Anthropization

Iberian peninsula

Landscape transformations

Late Holocene

Pyrenees

Palynology

Varved lake sediments

Vegetation dynamics

Western Mediterranean

\begin{abstract}
A B S T R A C T
The Pyrenean Lake Montcortès sediments hold the longest continuous and absolutely varve-dated record of the Mediterranean region, encompassing the last three millennia, from the Late Bronze Age to the present. The reconstruction of vegetation and landscape dynamics during this time period has advanced gradually, following the progress of absolute dating by varve counting, and has been progressively published and updated in a number of papers dealing with specific time intervals at different temporal resolutions. This paper synthesizes all these studies in a single composite paleoecological sequence constrained by a single age-depth varve model. The final resolution of this reconstruction is bidecadal, on average, but some periods have been resolved at quasidecadal (Middle Ages) and subdecadal (Modern Age to present) resolutions. The study is focused on the timing of anthropization and the further development of vegetation under climatic and anthropogenic drivers until the shaping of present landscapes. An additional advantage of Montcortès is that the local history of the Pallars region, where the lake is located, is well documented and can be easily correlated with the paleoecological record. Contrary to former interpretations of general landscape anthropization of the Pyrenees during the Middle Ages, the Montcortès catchment was irreversibly transformed by anthropic activities at the beginning of the Iron Age (ca. 750-650 BCE). From this point, the catchment underwent successive transformations due to varied human uses (fire, grazing, cereal cultivation, weed/ruderal plant expansions, hemp cultivation/retting), which have been related to the different cultural phases and sociopolitical changes documented in the local historical records. The regional forests, dominated by Pinus and Quercus, experienced four main clearance events (RD) during the Iron Age (RD1; ca. 300 BCE), the Roman Period (RD2; ca. 300 CE), the Middle Ages (RD3; ca. 1000 CE) and the Modern Age (RD4; ca. 1800 CE). The detailed trends of the last two deforestation events and their causes could be studied at a decadal resolution, which significantly improved interpretation quality in ecological terms. The potential effects of climatic changes and the eventual interactions with human activities on catchment vegetation and regional forests throughout the record have also been discussed. The Montcortès record has been compared with other records at local (Pyrenees), regional (Iberian Peninsula) and biome (Mediterranean) scales. Locally and regionally, anthropization times and further ecological trends showed significant heterogeneity according to elevation, biogeographical patterns and cultural trends. The most significant coincidence is an intensification of human pressure, as noted in forest clearing and extensive land use, during several phases of the Middle Ages. At the Mediterranean level, the Montcortès record emerges as a unique sequence for the western sector of this biome that should be complemented with similar
\end{abstract}

\footnotetext{
* Corresponding author.

E-mail address: vrull@csic.es (V. Rull).
} 
archives from the central and eastern Mediterranean. The most promising candidates for such sequences are discussed on the basis of available Mediterranean varved records.

() 2021 The Author(s). Published by Elsevier Ltd. This is an open access article under the CC BY license (http://creativecommons.org/licenses/by/4.0/).

\section{Introduction}

The formation of varved, or annually laminated, sediments requires marked seasonality in climate and sedimentary processes in lakes, and varve preservation is favored in small and deep lakes with a permanent or seasonal anoxic/hypoxic hypolimnion. These conditions are more frequent in northern temperate and boreal areas (Fig. 1) and have provided numerous high-resolution reconstructions of a wide range of trends and processes, including paleomagnetism, solar forcing, volcanic and seismic activity, climate change, ecological shifts and human activities (O'Sullivan, 1983; Ojala et al., 2000; Zolitschka et al., 2015). At lower latitudes, long and continuous varved records are less frequent. For example, in the Mediterranean region, Zolitschka et al. (2015) identified only a tenth of lakes as having varved sediments, four in the Iberian Peninsula (Fig. 1). The varved records of these lakes are of variable extension and provide absolute (anchored to the varve corresponding to the coring date) or floating (not tied to present day or any other absolute time marker) chronologies. The lakes with floating chronologies are Arreo (46 yr) and Zóñar (637 yr) (Corella et al., 2011b; Martín-Puertas et al., 2008). The lakes with absolute chronologies are La Cruz (423 yr) and Moncortès (2699 yr) (Romero-Viana et al., 2008; Corella et al., 2016). Therefore, Lake Montcortès, situated in the lower montane belt of the
Iberian slopes of the central Pyrenees, may be considered an exceptional case in the western Mediterranean region because its sediments contain a continuous varved record, which allows highresolution paleoclimatic and paleoecological reconstructions of roughly the last three millennia.

Lake Montcortès varves are of two types or microfacies. Facies M1 includes the classic biogenic varves from lakes on carbonate bedrock and is formed by a white calcite layer and a brownish organic layer. Facies M2 has an additional detrital layer between the calcite and organic laminae. The total thickness of the varves is highly variable, ranging from 0.05 to $31.1 \mathrm{~mm}$ (Corella et al., 2012). The white calcite layer formed mostly during summer/fall, and the brown organic layer was deposited mostly during winter/spring (Trapote et al., 2018a). Intermediate detrital layers of Facies M2 were deposited occasionally by runoff during intense rainfall episodes (Corella et al., 2014). Sedimentological studies of Lake Montcortès varved sediments have provided high-resolution paleoclimatic reconstructions for the last three millennia. Especially noteworthy are studies on heavy rainfall event (HRE) variability and on sediment yield (SY) trends in the lake in relation to climate and human activities. Corella et al. $(2016,2019)$ found that extreme HREs, as deduced from the irregularly distributed detrital layers, were correlated with negative phases of the Mediterranean Oscillation (MO), whereas SY variability was affected by both flood

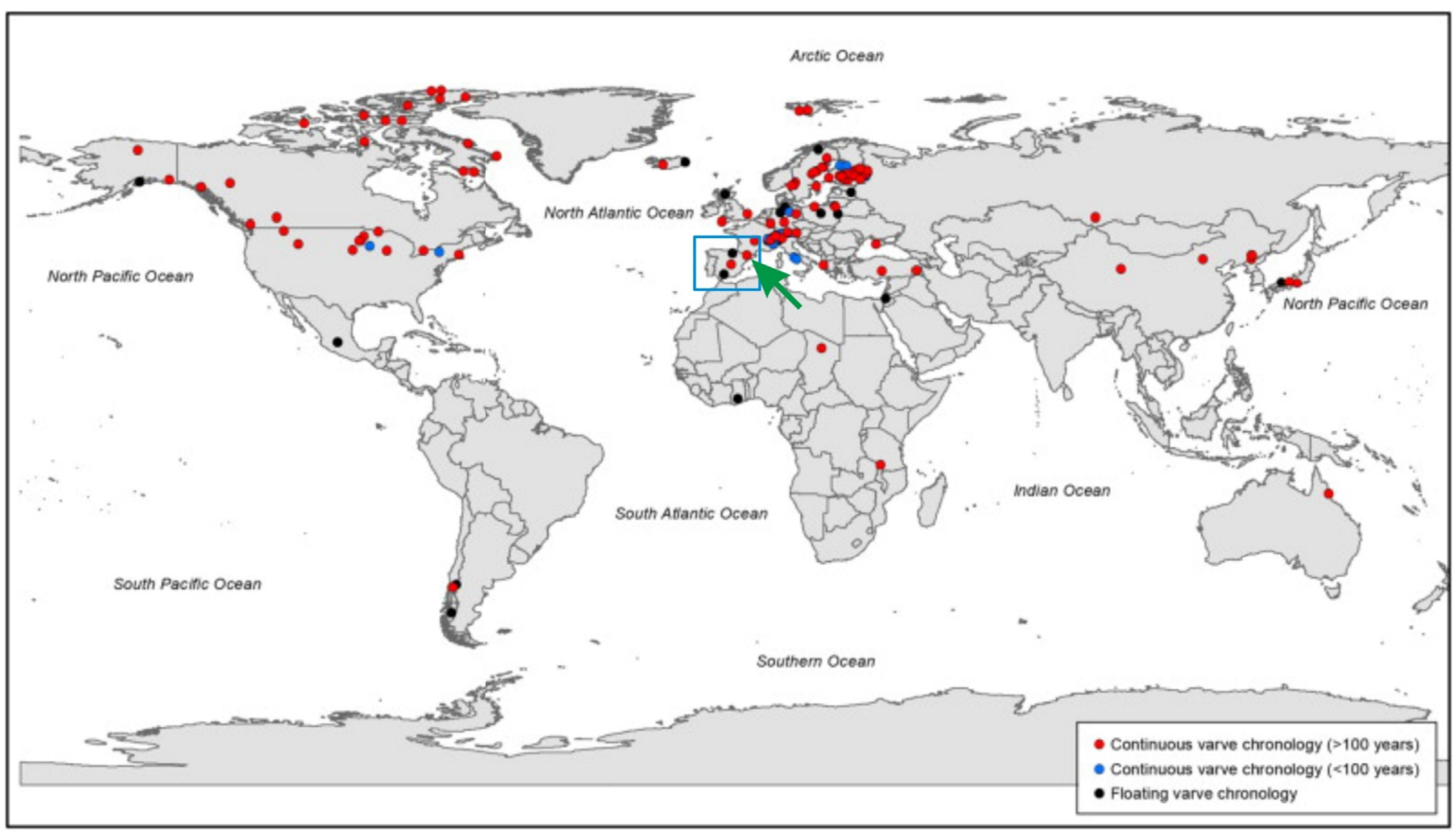

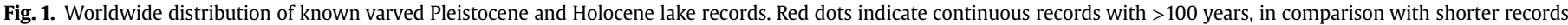

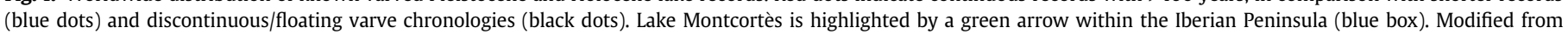
Zolitzschka et al. (2015). (For interpretation of the references to color in this figure legend, the reader is referred to the Web version of this article.) 
variability and human land use.

Palynological analyses of Lake Montcortès sediments have been conducted discontinuously as varve dating has progressed and have been published in separate papers accounting for different time intervals at different temporal resolutions. The first palynological analyses covered roughly the last millennium, from Medieval times to the Modern Age ( $830 \mathrm{CE}$ to $1880 \mathrm{CE}$ ), at a multidecadal resolution (Rull et al., 2011). Later, the age-depth model was refined, and the palynological sequence was updated accordingly (Rull \& VegasVilarrúbia, 2014, 2015, 2015; Montoya et al., 2018). A further study increased the resolution of the last ca. 500 years (1420 CE to 2013 CE) to the subdecadal scale and added the last century, representing the Industrial Revolution and the Global Warming, which were absent in previous studies (Trapote et al., 2018b). All these time intervals were characterized by a dominant anthropogenic forcing, mainly by burning, cultivation and grazing, since $830 \mathrm{CE}$ (Rull and Vegas-Vilarrúbia, 2015; Montoya et al., 2018). Once the entire Montcortès laminated record was dated by varve counting, the third step consisted of the analysis of the pre-Medieval interval representing the Late Bronze Age, the Iron Age and the Roman Period (ca. $1100 \mathrm{BCE}$ to $820 \mathrm{CE}$ ). In this case, the most relevant conclusion was that irreversible landscape anthropization took place in the Iron Age (ca. 750 BCE), rather than in the Middle Ages, as previously thought (Rull et al., 2021).

Combining these partial palynological studies, it is possible to obtain a complete record of vegetation and landscape dynamics during the last three millennia and to infer the potential climatic and anthropogenic drivers involved. This paper is a synthesis of the former palynological studies using a single unified absolute agedepth model based on the most updated varve counting. The ecological history of the catchment and the region around Lake Montcortès is presented in a single pollen diagram organized by cultural phases, which is compared with the results of previous sedimentological studies and the available paleoclimatic, historical and archaeological information. Emphasis is placed on anthropization and the potential synergies between climatic and anthropogenic drivers in the shaping of current and historical landscapes. The information obtained is placed in a Pyrenean context considering the available paleoecological studies across elevational gradients, from the basimontane to alpine level. Comparisons with the landscape anthropization timing of other sites from Mediterranean Iberian ranges situated at elevations similar to that of Lake Montcortès are also attempted. Finally, the Montcortès record is compared with other varved records across the whole Mediterranean region to pave the way towards an eventual regional picture of high-resolution paleoecological and anthropization records.

\section{Study site}

Lake Montcortès (Fig. 2) is located at $42^{\circ} 19^{\prime} 50^{\prime \prime} \mathrm{N}-0^{\circ} 59^{\prime} 41^{\prime \prime}$ and a $1027 \mathrm{~m}$ elevation, in the southern-central Pyrenean flank, in the historical region of Pallars (Catalonia, NE Spain) (Figs. S1 and S2; Supplementary Material). Geologically, the lake lies in a karstic terrain characterized by Triassic limestones, marls, evaporites, and Oligocene carbonatic conglomerates. Triassic ophytes outcrop mainly in the south, and Quaternary lacustrine sediments surround the present-day waterbody (Corella et al., 2011a; Gutiérrez et al., 2012). The climatic data for the 1996-2020 period from the nearby La Pobla de Segur weather station (Fig. 2), which is situated approximately $9 \mathrm{~km}$ to the south at a 513 m elevation, show that the annual average air temperature of the area is $13.7^{\circ} \mathrm{C}$, ranging from $3.5^{\circ} \mathrm{C}$ in January to $24.3^{\circ} \mathrm{C}$ in July. The total annual precipitation is $581 \mathrm{~mm}$. February is the driest month $(19.4 \mathrm{~mm})$, and May is the wettest month $(66.1 \mathrm{~mm})$. The predominant direction of the wind is SW during fall and winter, shifting to SSE during spring and summer.

The lake is kidney-shaped and small, with a diameter of $400-500 \mathrm{~m}$, a total surface area of $0.14 \mathrm{~km}^{2}$, and a maximum depth of $32 \mathrm{~m}$. The watershed is also small (approximately $1.4 \mathrm{~km}^{2}$ ), with a few intermittent small creeks and scattered springs, and the lake is fed primarily by groundwater. The lake was firstly considered to be meromictic (Camps et al., 1976), but some mixing events (holomixis) were occasionally observed in further studies (Modamio et al., 1988). A recent high-resolution study of the Montcortès sediments encompassing the last 500 years has shown that the lake cannot be unequivocally characterized as meromictic, as water mixing and hypolimnion oxygenation have experienced variations throughout history (Vegas-Vilarrúbia et al., 2018). At present, the lake is thermally stratified during most of the year, except in winter, when mixing events occur (Trapote et al., 2018a).

Lake Montcortès lies near the altitudinal boundary between submontane and montane vegetation belts, which in the Pyrenees is situated at approximately $800-1000 \mathrm{~m}$, depending on local conditions (Vigo and Ninot, 1987). Around this transitional boundary, four major forest formations occur representing the upper Mediterranean, submontane and montane stages: (i) Mediterranean sclerophylous forests of Quercus rotundifolia Lam; (ii) submontane deciduous oak forests of Quercus pubescens Willd. and Quercus subpyrenaica Villar; (iii) submontane conifer forests of Pinus nigra J.F. Arnold subsp. salzmanii (Dunal) Franco; and (iv) montane forests of Pinus sylvestris L. Pastures, meadows and crops are the main herbaceous vegetation types, whereas scrub, abandoned crops and badlands are in the minority. Locally, the lake is surrounded by an almost continuous belt of aquatic and semiaquatic vegetation dominated by Phragmites australis (Cav.) Steud., with Typha domingensis Pers. and Cladium mariscus (L.) Pohl. The local and regional flora and vegetation around Lake Montcortès have been described and mapped in detail elsewhere (Rull et al., 2011; Mercadé et al., 2013; Trapote et al., 2018b). Forest stands around the lake are dominated by deciduous Quercus (Fig. 2).

\section{Methods}

Pollen-analytical methods, diagram zonation and the use of modern analogs for interpretation in terms of vegetation and landscape changes are explained in detail in the original papers that are summarized here (Rull et al., 2011, 2017, 2021, 2017; Rull \& Vegas-Vilarrúbia, 2014, 2015, 2015; Montoya et al., 2018; Trapote et al., 2018b). In this paper, the methodological emphasis is on the construction of the composite section and the assembly of the synthetic pollen diagram, as well as its interpretation. The composite section was obtained by the combination of five cores retrieved during the coring campaigns of 2004 and 2017. The criterion for combining these cores was chronological, after dating by varve counting.

Lake Montcortès age-depth model (Fig. 3) consisted on an independent absolute varve chronology for the upper $543.5 \mathrm{~cm}$ of sediment, spanning since 763 BCE until the present (Corella et al., 2016) and an extrapolated chronology for the interval $543.5-573 \mathrm{~cm}$ assuming linear accumulation rates similar to the overlying samples, providing a basal age estimated at 1100 BCE (Rull et al., 2021). Varve counting was performed with an optical microscope with a $50 \mathrm{X}$ to $100 \times$ magnification depending on the layer thicknesses. For the interval covering the period 118 yrs CEPresent day varves were very well preserved and only $1.2 \%$ of this interval required interpolation by using the mean varve thickness of the upper and lower centimeters of the interpolated intervals (Corella et al., 2016). The interval 117 yrs CE- 763 yrs BCE showed poorer varve preservation requiring varve interpolation in $37 \%$ of the cases adding more uncertainty to the age-depth model (Corella 

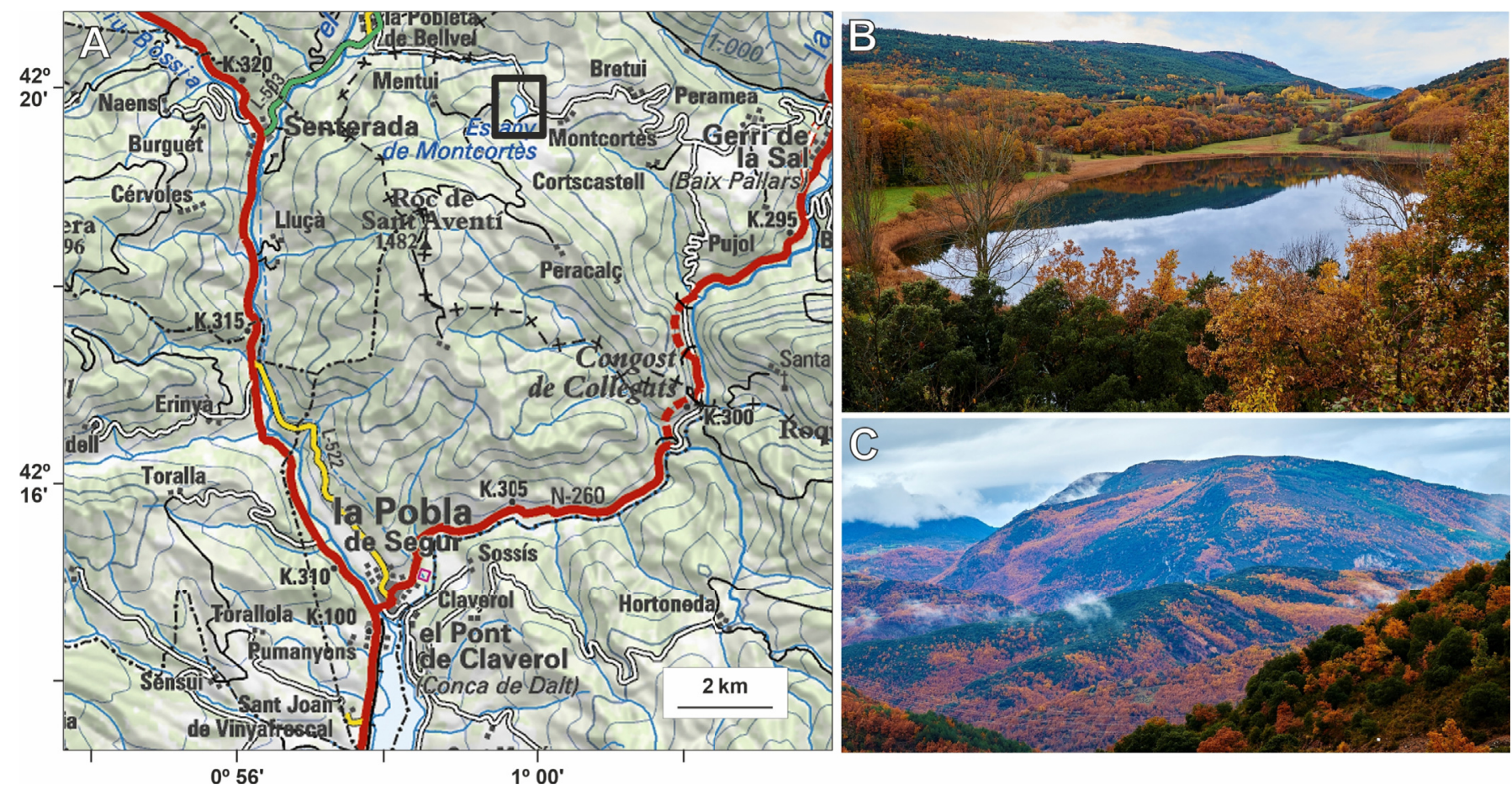

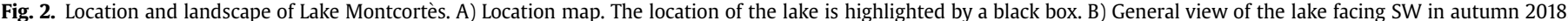

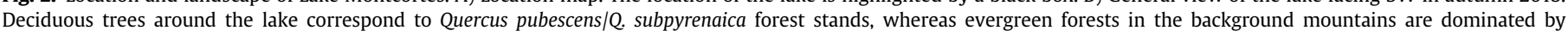

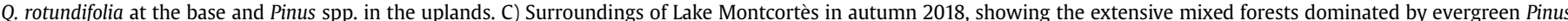

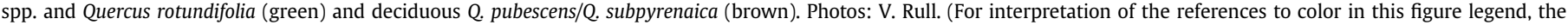
reader is referred to the Web version of this article.)

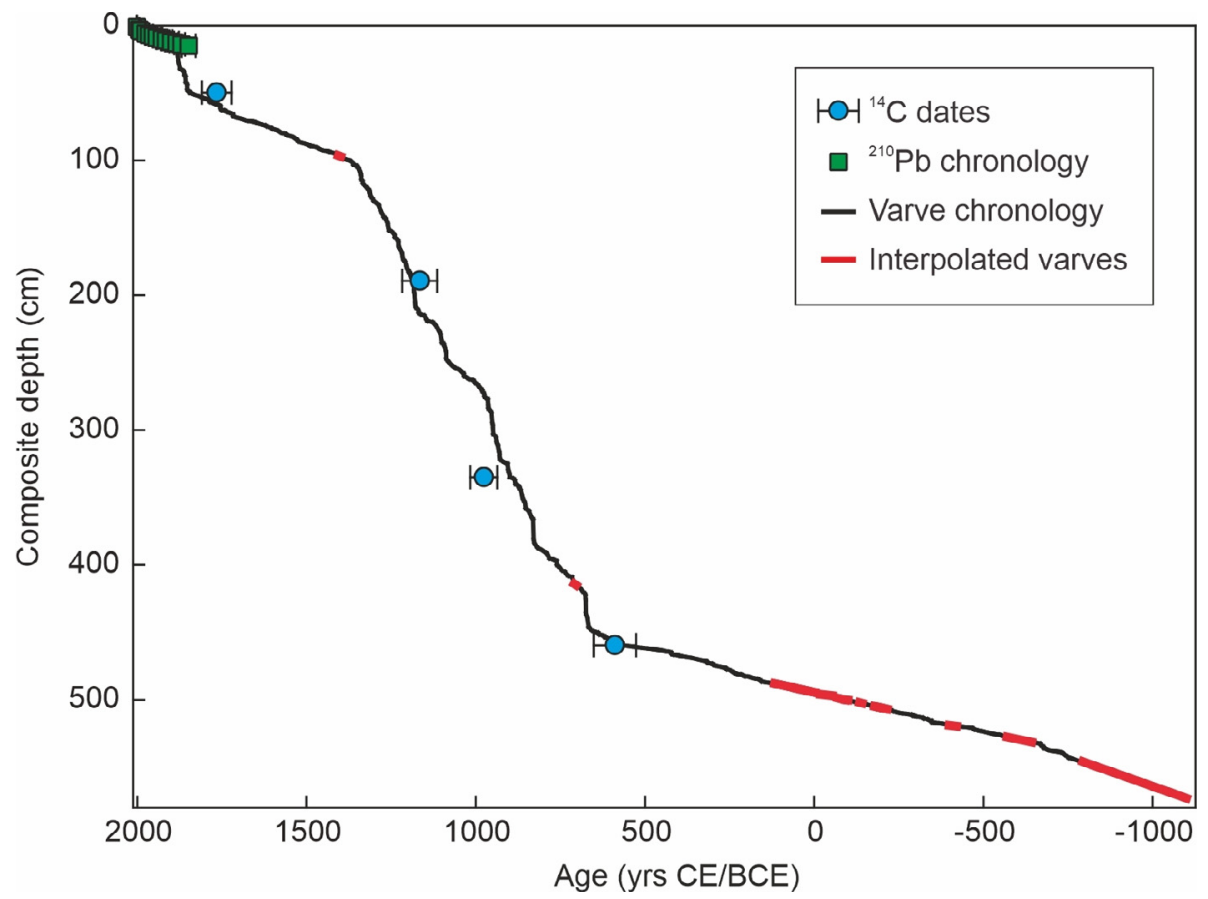

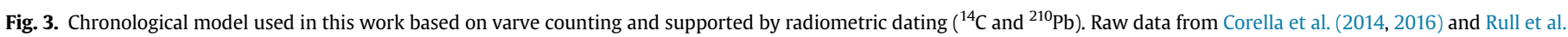
(2021).

et al., 2016). The varved age-depth model shows very good agreement with two independent dating methods based on radiometric dating techniques (AMS 14C and $210 \mathrm{~Pb}$ ) (Corella et al., 2012, 2014, 2016). The good correlation of the varve counting with the radiometric age-depth model verifies the annual nature of the laminations (Fig. 3). Sedimentation rate (SR) changes mostly depend on the allocthonous input to the lake during run-off events displaying periods with enhanced sediment delivery between 1901 


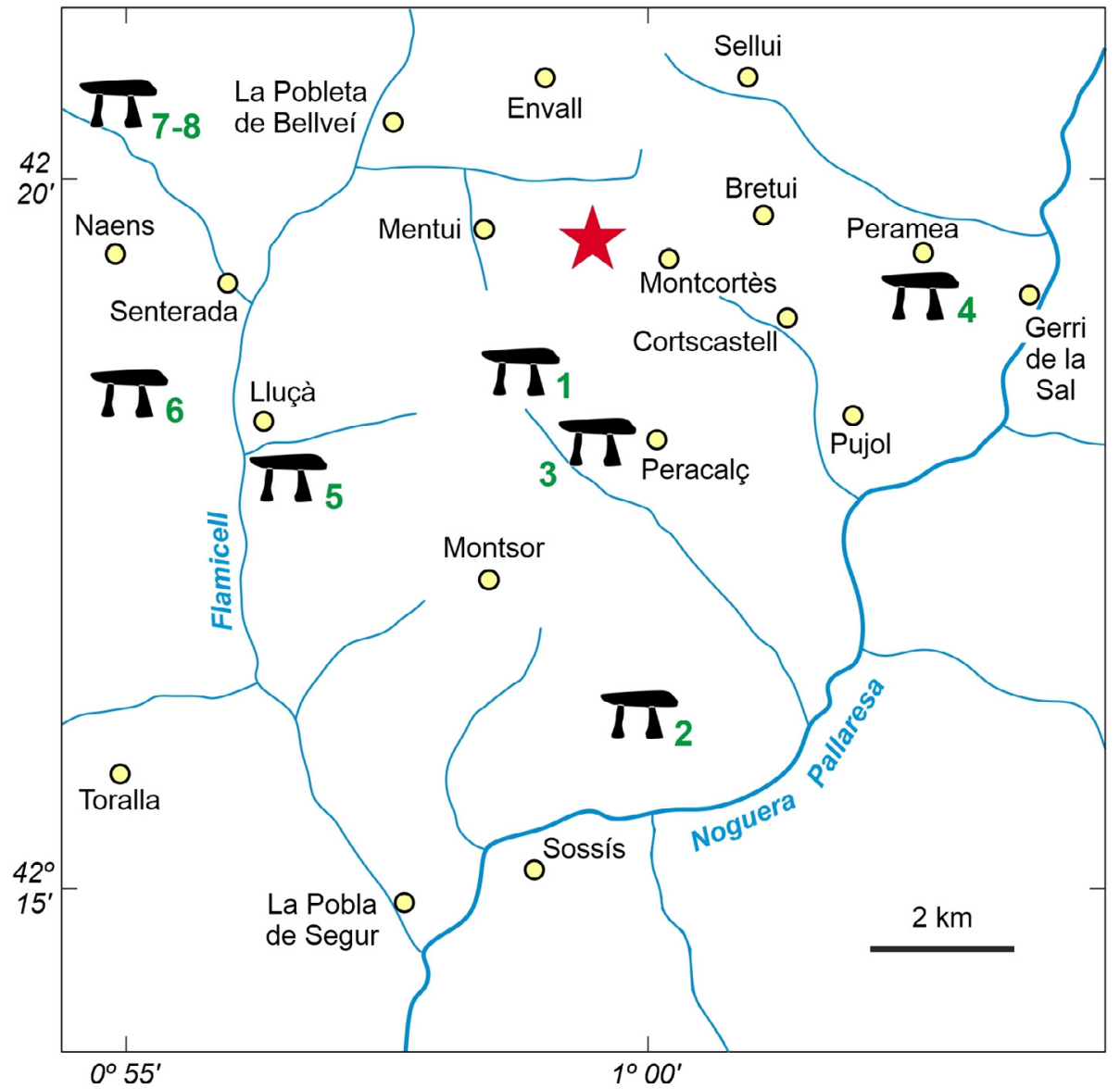

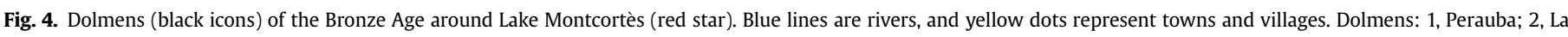

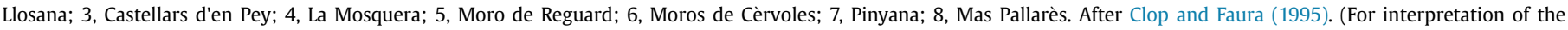
references to color in this figure legend, the reader is referred to the Web version of this article.)

and $1852 \mathrm{CE}$ and 1362-563 CE (SR of 0.69 and $0.45 \mathrm{~cm} / \mathrm{yr}$, respectively). On the other hand, the periods CE 2012-1902 ad CE 18511363 display very similar SRs of 0.12 and 0.11 respectively. The period 562 CE-BCE 762 showed a very constant sedimentation rate of $0.6 \mathrm{~cm} / \mathrm{yr}$ mostly due to the lack of thick turbidites. The latter SR was used to extrapolate the basal age of the studied sedimentary sequence since that interval showed relatively similar environmental conditions in terms of sediment delivery to the lake and vegetation cover (Rull et al., 2021) (Fig. 3).

Due to the objectives of the original studies, the presence of frequent turbiditic intervals of variable thickness and the occurrence of minor gaps between adjacent cores, the sampling resolution was variable. The average resolution per core ranged from subdecadal to multidecadal, and the maximum resolution was attained in the Early Middle Ages (669 CE - 821 CE) (core MON043 A-1K-4) and the last ca. 1400 years (core MON-0713-G05)
(Table 1). The overall resolution was bidecadal (16.3 years per sample or 6.1 samples per century). Given the thickness of the varves, which are millimetric to submillimetric (see above), this is the maximum sampling resolution that could be attained for pollen analysis, avoiding turbidites. There is an overlap of almost 460 years ( $1423 \mathrm{CE}$ to $1881 \mathrm{CE}$ ) between the upper two cores (MON-0713-G05 and MON04-1 A-1K). To assemble the composite section, the upper part of core MON04-1 A-1K was not considered, as core MON-0713G05 was analyzed at greater resolution (Table 1). However, the chronological homogeneity of these results with former lowerresolution analyses of the upper half of core MON04-1 A-1K (Rull et al., 2011) was carefully checked. Another relevant observation is the lack of sediments corresponding to the interval 8 BCE to 148 $\mathrm{BCE}$, which coincides with the contact between drives 4 and 5 of core MON04-4 A-1K.

The synthetic diagram was built using the most abundant and

Table 1

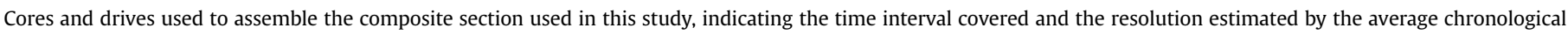
difference between samples ( $\mathrm{yr} / \mathrm{s})$ and the average number of samples per century $(\mathrm{s} / \mathrm{t})$. Extrapolated ages are in brackets.

\begin{tabular}{|c|c|c|c|c|c|c|c|}
\hline Core/drive & Time interval & Years & Samples & $\mathrm{yr} / \mathrm{s}$ & $\mathrm{s} / \mathrm{c}$ & Resolution & References \\
\hline MON-0713-G05 & $1423 \mathrm{CE}-2013 \mathrm{CE}$ & 590 & 95 & 6.21 & 16.10 & Subdecadal & Trapote et al. (2018a, 2018b) \\
\hline MON04-1 A-1K & $828 \mathrm{CE}-1881 \mathrm{CE}$ & 1053 & 36 & 29.25 & 3.42 & Multidecadal & Rull et al. (2011); Rull and Vegas-Vilarrúbia (2015); Montoya et al. (2018) \\
\hline MON04-3 A-1K-4 & $669 \mathrm{CE}-821 \mathrm{CE}$ & 152 & 20 & 7.60 & 13.16 & Subdecadal & Rull et al. (2021) \\
\hline MON04-4 A-1K-4 & $8 \mathrm{BCE}-659 \mathrm{CE}$ & 667 & 19 & 35.11 & 2.85 & Multidecadal & Rull et al. (2021) \\
\hline MON04-4 A-1K-5 & $(1100 \mathrm{BCE})-148 \mathrm{BCE}$ & 952 & 22 & 43.27 & 2.31 & Multidecadal & Rull et al. (2021) \\
\hline Total & $(1100 \mathrm{BCE}-2013 \mathrm{CE}$ & 3113 & 192 & 16.21 & 6.17 & Bidecadal & This paper \\
\hline
\end{tabular}


representative pollen types and assemblages to attain a homogeneous representation of vegetation succession over time. Pollen assemblages were defined according to modern vegetation types, as explained in detail in former papers (Rull et la., 2011; Trapote et al., 2018a, 2018b). This selection and assembly task was carried out with the participation of all palynologists involved in the original papers. Other pollen taxa may occur for several vegetation types and/or lack sufficient taxonomic resolution. These pollen types occur only occasionally and in low numbers and have not been included in the analyses. See Rull et al. (2011) and Trapote et al. (2018b) for more details. In addition to pollen taxa, other nonpollen palynomorphs (NPPs) with high indicator power have also been considered. This is the case for some genera of fungal spores, such as the coprophilous genera Sporormiella and Sordaria, which are indicative of grazing, and Glomus, which has been related to increased erosion rates (Montoya et al., 2018). Microcharcoal particles are well-known proxies for fire incidence, and some characteristic algal remains, especially of Pediastrum and Botryococcus, are used as proxies for limnological conditions, mainly lake levels and trophic state (Smittenberg et al., 2005). The interpretation of the pollen diagram followed the same criteria as former studies, which were based on a 2-year modern analog study using submerged pollen traps (Rull et al., 2017). This study demonstrated that regional vegetation is mainly represented by Quercus and Pinus pollen, whereas most of the remaining pollen types represent the local vegetation of the Montcortès catchment.

Vegetation change, as deduced by palynological analysis, is compared with cultural and climatic trends and events to infer the potential influence of natural and anthropogenic drivers on landscape dynamics. The account is disclosed following the cultural phases of the Pallars region, namely, Bronze Age (2700-800/750 BCE), Iron Age (800/750-450 BCE), Roman epoch (72 BCE-418 CE), Middle Ages (418-1488 CE), Modern Age (1488-1789 CE) and contemporary times (1789-present), and the vegetation trends are compared with the main protohistorical and historical developments and events that could have been linked to vegetation/ landscape change. All this information has been taken from Marugan and Rapalino (2005) and is described in more detail in the Supplementary Material.

The paleoclimatic context is provided by former sedimentological and geochemical studies of Lake Montcortès sediments (Corella et al., 2016, 2019) and the general climatic phases known for continental Europe: Iron Age Cold Period (IACP; 900-300 BCE), Roman Warm Period (RWP; 250 BCE-400 CE), Iberian-Roman Humid Period (IRHP; 650 BCE-350 CE), Dark Ages Cold Period (DACP; 400-850 CE), Late Antique Little Ice Age (LALIA; 540-660 CE), Medieval Climate Anomaly (MCA) or Medieval Warm Period (MWP) (950-1250 CE), Little Ice Age (LIA; 1300-1800 CE) and Global Warming (GW; 1850 onward) (Gribbin and Lamb, 1978; Mann et al., 2009; Martín-Puertas et al., 2009; Büntgen et al., 2016; Helama et al., 2017). Unfortunately, no paleotemperature reconstructions of the last 3000 years are available for Lake Montcortès and similar Pyrenean areas. Therefore, a combination of paleotemperature curves from a nearby high-elevation Pyrenean locality and others from northern Iberia (Cantabria) and central Europe (Alps) are used for comparison (Martín-Chivelet et al., 2011; Catalan et al., 2013; Affolter et al., 2019).

\section{Vegetation and landscape dynamics}

Before starting with vegetation/landscape reconstruction, a clarification regarding the difference between human settlement and landscape anthropization seems opportune. Previous studies on a variety of Pyrenean valleys situated at different elevations have shown that initial human settlement and landscape anthropization
- i.e., the large-scale irreversible transformation of a landscape leading to its present-day configuration - may be lagged by centuries or millennia (Rull and Vegas-Vilarrúbia, 2021). Human settlement is usually recorded by archaeological evidence, whereas anthropization records need palynological evidence to infer significant vegetation and landscape transformation.

According to the available archaeological evidence, humans inhabited the region around Lake Montcortès at least since the beginning of the Bronze Age (Fig. S3; Supplementary Material). This evidence includes numerous megalithic constructions (dolmens) (Fig. 3), cave dwellings and other archaeological sites with skeletons, ceramics, artifacts, charcoal and a diversity of materials and structures that provide evidence of regular human settlement and activities such as burial, food storage and salt extraction from groundwater springs, among others (Panyella, 1944; Clop and Faura, 1995; Simon and Vicente, 2002; Piera, 2013; Piera et al., 2013). The earliest radiocarbon age available corresponds to a human skeleton dated to 3770 cal yr BP (1820 BCE; Middle Bronze Age), which is consistent with ceramic stylistic features (Piera, 2013; Piera et al., 2013). In summary, humans were already present in the region around Montcortès during the Early/Middle Bronze Age, but the anthropization of the lake catchment and its surroundings, as documented by palynological records, did not occur until $>1300 \mathrm{yr}$ later, at the beginning of the Iron Age (Rull et al., 2021).

The following sections provide a synthetic account of the main paleoecological, cultural and climatic trends and events of the last ca. 3000 years in the Lake Montcortès catchment and the surrounding areas, organized by cultural and historical periods.

\subsection{Late Bronze Age (ca. 1100 to $800 / 750$ BCE)}

The Late Bronze Age was characterized in Montcortès by the most undisturbed vegetation documented along the whole sedimentary record, both in the lake catchment and the surrounding region. During the Late Bronze Age, regional forests were dominated by deciduous and evergreen Quercus forests (the deciduous oaks were slightly dominant), and pine forests were less abundant, except for a peak at ca. 960 BCE (Fig. 5). In the lake catchment, the dominant vegetation type was the gallery forest composed of Alnus and Corylus, a common association known as Alnetum catalaunicum (a type of Alnetum glutinosae) that occurs today along rivers and around lakes in the central Pyrenees above 600-800 m elevations (Folch et al., 1984; Loidi, 2017). Interestingly, this association is absent in the present Montcortès catchment (Mercadé et al., 2013). Shrubby and herbaceous vegetation types were very scarce, which suggests that the catchment was mostly forested. Indicators of anthropogenic activities (cereals, coprophilous fungi) are also very scarce or absent, and the low charcoal values indicate reduced fire incidence. The whole picture suggests a totally forested landscape with very little or no human impact.

According to archaeological evidence, megalithism was declining in the region, and human populations were restricted to small nomadic pastoralist groups living in caves or in outdoor settlements depending on the season (Cots, 2005). No evidence of human settlements has been found in the Montcortès catchment for the Late Bronze Age, which is consistent with the occurrence of mostly undisturbed gallery forests. No studies on heavy rainfall events (HREs) or sediment yield (SY) in the lake exist for this period, which lacks varve dating, due to the occurrence of nonbiogenic laminations, whose seasonal nature is not guaranteed. However, the dominance of organic varves and the scarcity of detrital layers point to reduced sediment input from the watershed, as expected in a forested landscape. The age of this section has been extrapolated assuming constant sedimentary rates similar to those 


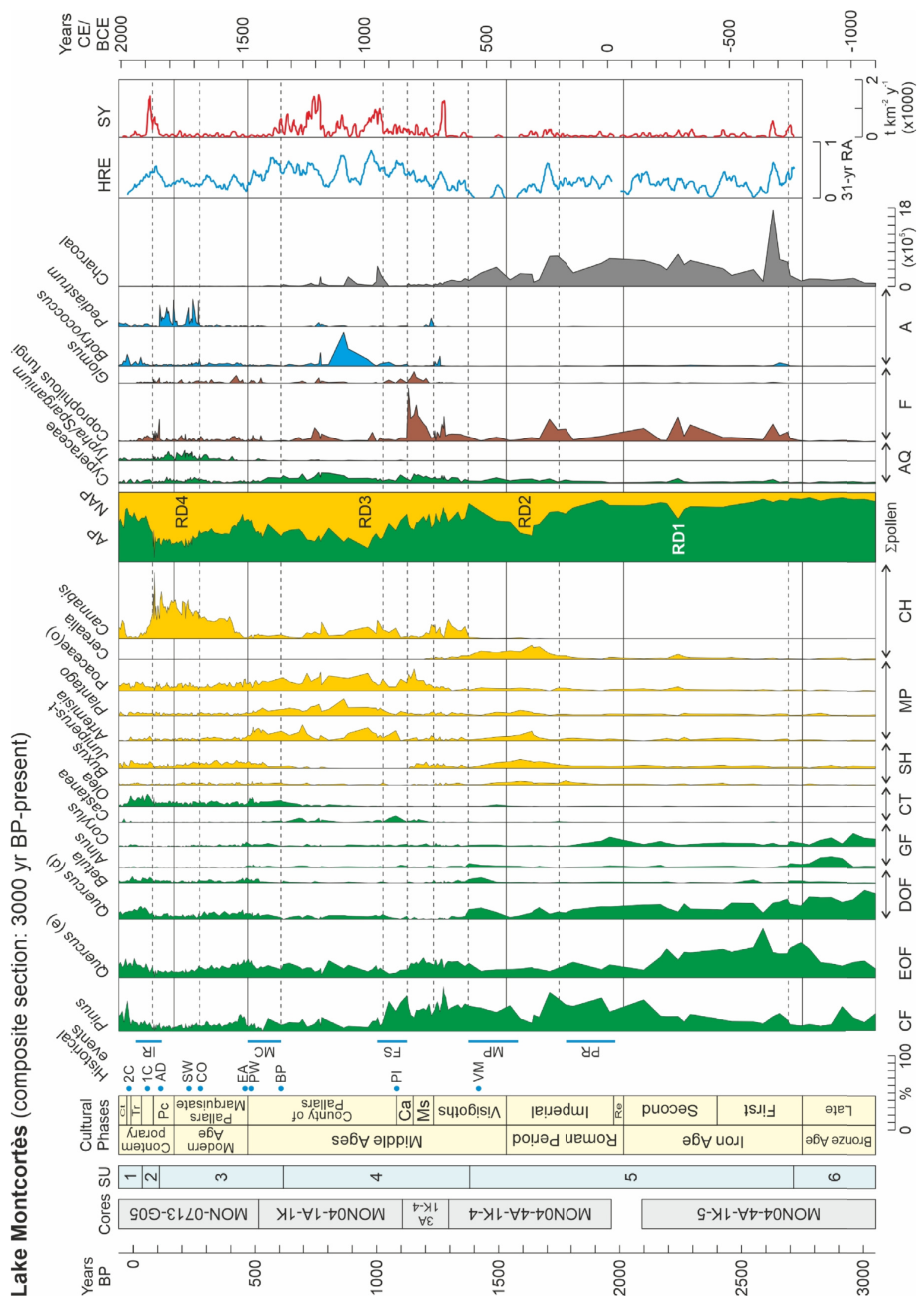


in the upper varve-dated Iron Age interval (Rull et al., 2021). The Late Bronze Age was characterized by warmer climates (Fig. 6) that may have favored dominance around the lake catchment of Mediterranean Quercus forests, which occur at lower elevations than montane pine forests (Mercadé et al., 2013).

Due to the lack of older sediments, it is still premature to assess whether the fully forested Montcortès landscape of the Late Bronze Age was primeval or resulted from the recovery of an eventual former anthropogenic disturbance. It would be especially interesting to know the potential influence of human groups that built the Early Bronze megaliths in the landscape around Montcortès (Fig. 3). Further coring efforts are needed to test these insights. The absence of biogenic laminations is also an interesting topic to be investigated. The nonbiogenic nature of the laminations corresponding to the Late Bronze Age has been deduced from the absence of the calcite layer characteristic of biogenic laminations. A possible explanation is that organic matter accumulation would have lowered the $\mathrm{pH}$ of deep anoxic waters, thus preventing the preservation of the calcite layer by carbonate dissolution (Corella et al., 2011a). However, more studies are necessary for a sound assessment.

\subsection{Iron Age (800/750 BCE to $72 \mathrm{BCE})$}

The Iron Age represented the time of full transformation of the vegetation and landscape in the Montcortès catchment. Regional forests also experienced a slight reduction and some changes in composition. In these forests, the dominance changed from deciduous to evergreen Quercus until ca. $150 \mathrm{BCE}$, when pine forests began to dominate at the expense of evergreen Quercus, which underwent a significant decline (Fig. 5). In the catchment, the Alnus-Corylus gallery forests disappeared but were not replaced by herbaceous formations or crops, suggesting degradation of the watershed vegetation, likely manifested in a significant decline in plant cover. This thorough landscape transformation coincided with the first peak of coprophilous fungi and fire (ca. 750-650 BCE), suggesting that gallery forests around the lake were burned and transformed into pastures.

This abrupt anthropization of the lake catchment coincided with an increase in HREs that, combined with soil denudation (Rull et al., 2021), resulted in an increase in SY to the lake. Fire and grazing continued until the end of the Iron Age, which prevented the recovery of watershed vegetation. Grazing activity experienced a second maximum by ca. 300 BCE, coinciding with a small peak of cereal cultivation and a small deforestation event in regional forests (RD1; Fig. 5), coeval with a fire peak. This was the culmination of a gradual decrease in regional forests that coincided with an increasing trend in fire and grazing. After this, a change in regional forest composition was characterized by the decline of Quercus (e) and the dominance of Pinus (ca. 250-150 BCE). HREs fluctuated around intermediate values with minima at ca. 600 and 400 BCE and a maximum at approximately 500 BCE. SY values remained low throughout the Iron Age. The Montcortès anthropization event also coincided with the onset of biogenic varve formation, suggesting a close relationship between this sedimentary feature and anthropogenic pressure. It is possible that higher runoff increased the carbonate and nutrient inputs, leading to better conditions for seasonal calcite precipitation, including increased primary productivity in the aquatic ecosystem and subsequent varve formation (Corella et al., 2012). Sedimentary facies also suggest that biogenic varve formation coincided with a change from a shallower to a deeper lake with a well-developed anoxic hypolimnion, which favors the formation of biogenic laminations (Corella et al., 2011a).

Culturally, the Iron Age has been subdivided in the Pallars region into two phases with the boundary at 450 BCE (Fig. S3; Supplementary Material). The first phase was similar to the Late Bronze Age in terms of human occupation, whereas the second phase was characterized by the maximum development of the iron industry, which implied demographic growth and a certain degree of social diversification. In the Montcortès catchment, these two phases did not have a relevant influence on human practices and land use, except for a more or less continuous but low-intensity regional deforestation trend coinciding with a gradual fire increase, probably as a result of demographic growth and the development of the iron industry. Climatically, the Iron Age was cooler (IACP) and wetter (IRHP) than the Late Bronze Age, especially during the first phase (Fig. 6). These trends would have favored progressive downward displacement of the forest belts consistent with the observed increase in montane pine forests around Lake Montcortès and the decline in oak forests, both deciduous and evergreen, which would have moved to lower altitudinal levels.

According to these results, anthropization of the Lake Montcortès catchment occurred during the Iron Age, significantly earlier than previously thought, and was performed by Iberian people. Former sedimentological studies interpreted the SY record mainly in terms of human pressure and proposed that the low SY values before the Middle Ages were indicative of low human activity around the lake (Corella et al., 2019). Similarly, archaeological evidence, notably the lack of settlement remains in the catchment and its surroundings, suggested that human impact would have been low until the Roman period (Cots, 2005). At a regional level, recent reviews for the central Pyrenees concluded that landscape anthropization occurred mainly in the Middle Ages with little spatial variability (González-Sampériz et al., 2017, 2019). The case of Montcortès, however, suggested the potential occurrence of spatiotemporal gradients in the Pyrenean anthropization (Rull and Vegas-Vilarrúbia, 2021).

\subsection{Roman Period ( 72 BCE to $418 C E$ )}

From a paleoecological point of view, the Roman period can be subdivided into two well-differentiated phases, with a transitional boundary centered at ca. $200 \mathrm{CE}$ (Fig. 5). The first phase represents the consolidation of the dominance of pine forests over the oak forests in the regional vegetation. In the lake catchment, the situation was similar to that in the Iron Age (fire, overgrazing and soil denudation), except for a small increase in Corylus, which suggests the reestablishment of stands of this tree, whose fruits (hazelnuts) were collected in the wild at wet sites (Peña-Chocarro et al., 2019). This phase ended with peaks in fire and grazing that gave way to

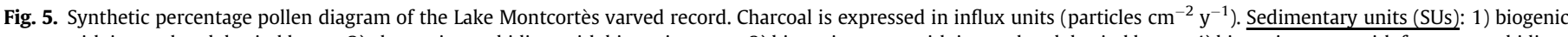

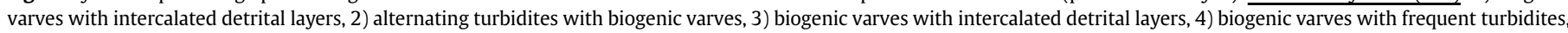

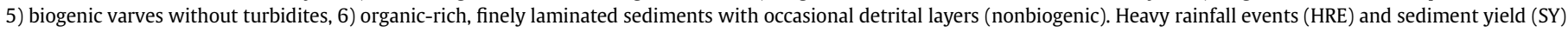

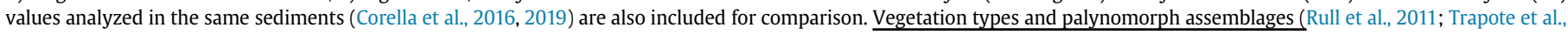

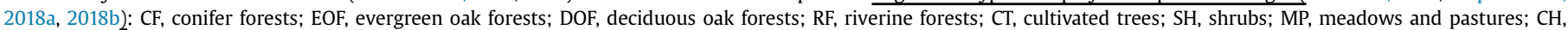

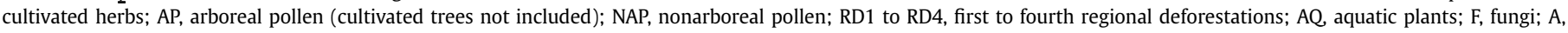

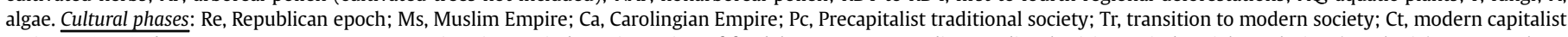

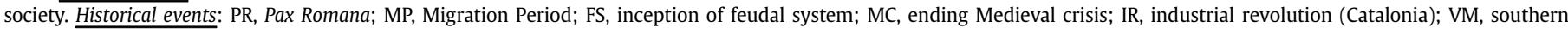

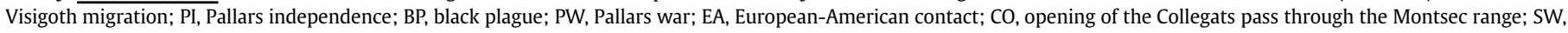
succession war; $A D$, dismantling of the Spanish royal navy; $1 C$, first demographic crisis; $2 \mathrm{C}$, second demographic crisis (see Supplementary Material for more information).
} 


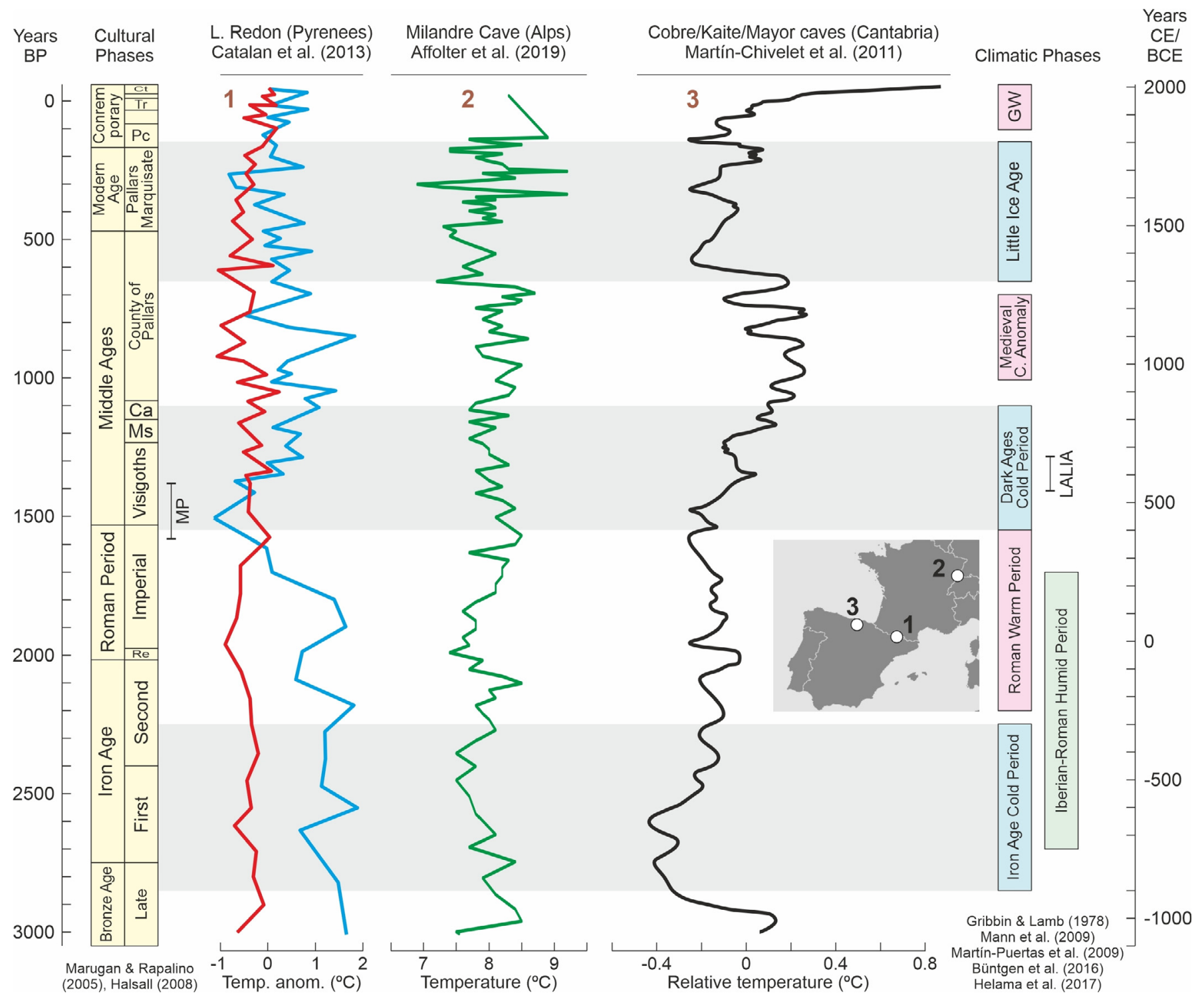

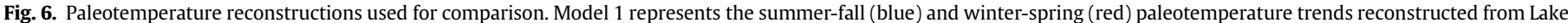

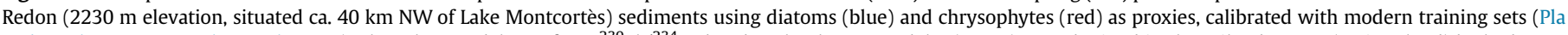

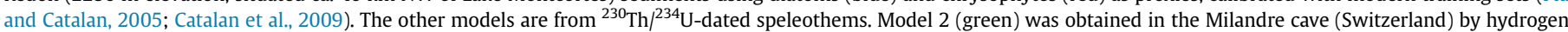

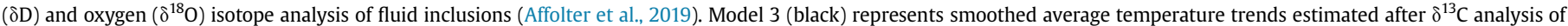

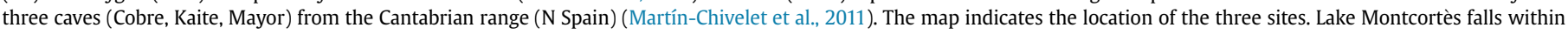
the white dot of site 1 . (For interpretation of the references to color in this figure legend, the reader is referred to the Web version of this article.)

the second phase, which was characterized by an abrupt decline (ca. $250 \mathrm{CE}$ ) and a subsequent recovery (ca. $400 \mathrm{CE}$ ) of Pinus, coinciding with an increase in shrubs, cereal crops and weeds (Plantago, Artemisia). This phase has been interpreted as a second anthropization pulse where intensive pastoralism was replaced by cereal cultivation inside the catchment, and selective pine exploitation began in the surrounding forests. This led to significant regional deforestation (RD2; Fig. 5), whose maximum was situated at approximately $300 \mathrm{CE}$. The decline in fire during the pine minimum suggests that these trees were probably cut down for wood instead of burned, a common practice among Romans (Veal, 2017). The recovery of shrubby vegetation may have been due to the regrowth of Buxus and Juniperus, which are secondary colonizers of deforested areas and abandoned terrains (Carreras et al., 2005-2006). Selective pine exploitation led to the first significant regional deforestation event recorded in the Montcortès sequence, peaking at ca. $320 \mathrm{CE}$. HREs and SY underwent a small increase, likely favored by a decrease in land cover by human pressure (Rull et al., 2021).

From a historical perspective, the Pallars region seems to have been considered a marginal region for the Roman culture, probably due to its physical isolation. Indeed, the Roman Pallars was mainly occupied by autochthonous Iberian people, and the Roman presence seems to have been scarce, despite them ruling the region according to their own laws (Cots, 2005). Notably, the first phase defined above where land-use practices were similar to those in the Iron Age roughly coincided with the Pax Romana (27 BCE-180 CE), a phase following the Republican period, which was characterized by general stability, order and prosperity that inaugurated the Roman Empire. There is no evident connection between this historical event and the paleoecological interpretation advanced here. Future multidisciplinary studies may be developed to find eventual 
relationships, but in the present state of knowledge, it is possible that Roman influence was not significant until the second paleoecological phase, when land use diversified. The available historical documents report subsistence economic practices (farming, forestry) combined with commerce and mining activities during the Roman occupation of the Pallars (Fig. S3; Supplementary Material). This would be consistent with the shift to cereal cultivation and selective forest exploitation during our second paleoecological phase, but more evidence is needed for a sound assessment.

At the regional scale, the climates were warmer (RWP) and wetter than those of the Iron Age (Fig. 6). However, the Pyrenean paleotemperature curve (Lake Redon) showed a pronounced decline between ca. 200 CE and the end of the Roman period not observed in other curves. This decline coincided with the second paleoecological phase, when intensive overgrazing was replaced by cereal cultivation and pine exploitation, which was possibly related to the increasing presence of Roman people in the Pallars region. This cooling also appears in Cantabrian cave reconstructions but at a lower intensity (Fig. 6).

\subsection{The migration period}

In general, the transition between Roman domination and the establishment of Middle Age cultures was not sudden but transitional and spanned approximately 200 years (ca. 370-570 CE), during which former Roman territories were invaded and occupied by other cultures, often called Barbarian (Halsall, 2008). In the Pallars region, this phase has not been formally described but coincided chronologically with the first half of the Visigoth period, named for the northern culture that crossed the Pyrenees. In this case, the Migration Period is important to separate from the rest of the Visigoth period because of the existence of relevant paleoecological differences. During the Migration Period, pine forests recovered, which suggests that selective pine exploitation ceased, but cereal cultivation continued as the main human activity (grazing intensity was as low as in the second Roman phase, and fires were clearly declining) (Fig. 5). This apparent continuity of Roman practices suggests that the Visigoths had not yet occupied the Pallars region, which is supported by historical evidence, as this culture began to expand to the south from the French city of Tolosa by $507 \mathrm{CE}$, when the Frank Empire conquered this city (Fig. S4; Supplementary Material). This occurred near the end of the Migration Period (Fig. 5). The whole picture suggests a relaxation of human activities, which coincided with a phase of minimum HREs and, as a consequence, low or null SY to the lake (Corella et al., 2019). At the end of the period, a short-lived increase in Betula suggests that this well-known secondary colonizer of forest clearings in mountain and high-latitude biomes (Dubois et al., 2020) could have colonized the open areas left by former shrublands and crops/pastures, including lake shores. The Migration Period coincided with the onset of a new cold period, the DACP, which is well represented in the local and regional paleotemperature curves (Fig. 6). Therefore, it is possible that lower temperatures were also linked to low human pressure by downward migration to the lowlands.

\subsection{Middle Ages (418-1488 CE)}

In the Middle Ages, two different historical phases can be distinguished. The first phase extended from the Visigoth period to the consolidation of the feudal system in the 10th century and will be called prefeudalism here. The second phase was characterized by the dominance of the feudal system and roughly coincided with the political independence of the Pallars as a county (920-1488 CE) (Fig. S4; Supplementary Material).

\subsubsection{Prefeudalism (507 CE to 10th century)}

After the migration period and the onset of the Visigoth occupation, human activities changed radically in the Pallars country and its surroundings. Pine forests continued to be the most abundant regional forests, but evergreen oaks expanded and deciduous oaks disappeared abruptly, possibly because of selective cutting (fires strongly declined). Cereal cultivation ceased, shrubs and weeds almost disappeared, and the Montcortès catchment started to be colonized by wild grass meadows (Poaceae), which were intensively grazed again. A new element, Cannabis (hemp), appeared for the first time in the Montcortès record. This significant shift in land use was the manifestation of a cultural change initiated with the Visigoth occupation that lasted until ca. $820 \mathrm{CE}$, including the ephemeral Muslim period and the first half of the Frank (Carolingian) domination (Fig. 5). Historically, this phase is poorly documented and is also known as the dark prefeudal period (Fig. S4; Supplementary Material). It is believed that this phase witnessed a reinforcement of pre-Roman (Iberian) local autochthonous cultures (Marugan and Oliver, 2005). According to historical documents, the disintegration of the Roman world was followed by deep transformations in land use, such as the expansion of bottom-valley agriculture, a significant increase in local mining and the development of extensive pastoralism, including horizontal transhumance. This is consistent with the increase observed in the grazing indicators (coprophilous fungi), which significantly increased during this phase until a maximum at ca. $820 \mathrm{CE}$. The sudden introduction of hemp is not mentioned in historical documents about Lake Montcortès, yet it was a significant and long-lasting feature, except during the Muslim phase, when the lake catchment was occupied by grass meadows and aquatic plants (Fig. 5). It is not clear whether hemp, which is characteristic of warmer lowlands, was cultivated around the lake or was transported from the surrounding lowlands for retting, or both (Rull et al., 2021).

Prefeudal times were wetter than the Migration Period, as suggested by the maintained increase in HREs (Fig. 5). SY also increased as a consequence of both soil denudation and erosion by the combination of enhanced grazing and precipitation. The increasing moisture trend, which would have favored forest growth, and the decreasing fire incidence suggest that the deforestation trend observed during prefeudal times was probably linked to forest exploitation for wood rather than to burning. Temperatures were similar to those in the Migration Period (DACP), with cooling intensification during the LALIA, occurring between ca. 540 and 660 CE (Büntgen et al., 2016). The onset of the LALIA roughly coincided with the shift from the Migration Period to the prefeudal Medieval phase, which suggests that some of the events observed at this boundary - e.g., the abrupt disappearance of the deciduous oaks or the replacement of cereal crops by hemp in the lake catchment - may have had some climatic influence.

\subsubsection{Feudalism (10th century to $1488 \mathrm{CE}$ )}

In the Pallars region, the feudal system initiated during the Carolingian period and was fully established in the 11th century (Fig. S4; Supplementary Material). The political independence of the County of Pallars was achieved in 920 CE (Marugan and Oliver, 2005). From a paleoecological point of view, this phase was rather homogeneous, except for some relevant features. Regionally, the most significant event was the dramatic decline in pine forests at the beginning of this phase, which signified a remarkable reduction in the regional forest cover (900-1000 CE) (Fig. 5). This was the second most significant regional deforestation (RD3), after that recorded during the end of the Roman period, and occurred during a phase of low fire incidence (except for some isolated peaks). Therefore, it is possible that tree felling for wood was the main 
cause. It is important to note that slash-and-burn practices and forest burning, in general, were abolished by the feudal system in order to have more control over arable lands and their use (Marugan and Oliver, 2005). A gradual forest recovery was observed during the rest of the feudal epoch due to the progressive increase in deciduous and evergreen Quercus. However, regional forests never attained the abundance observed in the early Roman and Visigoth periods. This will be discussed in more depth in the next section, which deals specifically with forest development during the Middle Ages.

Inside the catchment, the vegetation was mostly herbaceous and dominated by grass meadows and weeds (Artemisia, Plantago). Cereal cultivation had been abandoned during the prefeudal phase. Grazing was less intense than in former periods, probably due to the development of extensive horizontal transhumance (Fig. S4; Supplementary Material), which relaxed the local grazing pressure. The dominance of open landscapes and the increase in runoff, as expressed in the frequency of HREs and the appearance of Glomus, led to a significant increase in SY to the lake. In addition to grazing, the main human activity inside the catchment seems to have been hemp cultivation/retting, although the relatively low abundance of this pollen type suggests that the hemp industry was intended only for local consumption. The possibility of hemp cultivation around the lake would be supported by the coeval in situ occurrence of lowland wild and cultivated plants migrating upwards thanks to the warmer climates of the MCA (950-1250 CE) (Fig. 6). Indeed, previous analyses (Rull et al., 2011) recorded the occurrence, in the Montcortès catchment, of a low scrub community dominated by Rosmarinus and Helianthemum, which is characteristic of present Mediterranean dry lowlands situated below 800 m elevation (de Bolós, 2001). In addition, historical documents report that during the same epoch, warmer climates allowed extension of lowland crops such as vineyards and olive groves to elevations above $1000 \mathrm{~m}$, which include the Lake Montcortès catchment (Fig. S4; Supplementary Material). Under these climatic conditions, hemp cultivation for local subsistence purposes around the lake would have been likely and is supported by the pollen record (Fig. 5).

Hemp declined at ca. $1380 \mathrm{CE}$, coinciding with an increase in Olea, near the beginning of the LIA cooling (Figs. 4 and 5). In this case, olive cultivation around the lake is unlikely, and the presence of olive pollen is probably linked to its high upward dispersion capacity (Cañellas-Boltà et al., 2009). Therefore, the increase in Olea pollen would be more consistent with an expansion of this crop in the lowlands, likely due to climatically triggered downward migrations of people to the southern Pallars. The interval of hemp decrease and olive increase also coincided with a declining trend in HREs and the abrupt drop in SY (Fig. 5). This combination of events occurred during the ending Medieval crisis (1348-1487 CE), when the Pallars was significantly depopulated due to the coincidence of several limiting factors such as an extended black plague (1348 CE), wars, the already mentioned climatic cooling of the LIA and the collapse of the feudal system, mainly due to its unsustainability (Marugan and Oliver, 2005) (Fig. S4; Supplementary Material). This coincidence of sociopolitical and climatic factors would have promoted the abandonment of the Lake Montcortès catchment and its surroundings and the return of secondary colonizers (Juniperus, Buxus, Betula), as observed in the pollen diagram (Fig. 5).

\subsubsection{Medieval forests}

The history of Medieval forests deserves special attention, as this was the epoch of major anthropogenic disturbance in the Pyrenees in terms of deforestation and extensive land use (González-Sampériz et al., 2017, 2019, 2019; García-Ruiz et al., 2020; Rull and Vegas-Vilarrúbia, 2021). In this study, the combination of cores described in the methods section has enabled us to resolve the Medieval forest history of the Montcortès region at a quasidecadal resolution (ca. $13 \mathrm{yr} / \mathrm{sample}$, on average), which almost triples the resolution of previous studies (Rull et al., 2011). In this way, it has been possible to record not only the general forest trends over time but also more subtle shifts that were hidden in former surveys. As seen above, the largest deforestation observed in the Montcortès record (RD3; Fig. 5) occurred at approximately $1000 \mathrm{CE}$, roughly coinciding with the consolidation of the feudal system. This large-scale deforestation was the culmination of a trend initiated at the end of the Migration Period (570 CE), during the DACP.

This deforestation trend was underlain by minor forest clearing events defining deforestation-recovery cycles of a 33-76 yr duration (average of $55 \mathrm{yr}$ ) that occurred mainly during the prefeudal phase (Fig. 7). The further forest recovery lasted until the boundary between the Middle Ages and the Modern Age (ca. 1500 CE) and was also characterized by minor but longer deforestation-recovery cycles of a 77-140 yr duration (average of $114 \mathrm{yr}$ ). This suggests that higher-frequency deforestation events (HFDEs) of half a century recurrence prevented full forest recovery and produced a cumulative effect that significantly reduced the forest cover. On the contrary, when the recurrence of forest clearing events increased to a century (lower-frequency deforestation events or LFDEs), forests were able to recover and progressively expand. Therefore, the large-scale Medieval deforestation that occurred in the Montcortès region during the Middle Ages was not the consequence of a single abrupt event that, once ceased, permitted the recovery of forests. Rather, the difference between the deforestation and recovery trends lies in the frequency of minor deforestation events that occurred throughout Medieval period.

Regarding the causes, it has been pointed out that the consolidation of the feudal system involved the end of slash-and-burn farming practices and favored extractive forest practices (Marugan and Oliver, 2005). This is clearly visible in the synthetic pollen diagram (Fig. 5), where the fire proxy (charcoal influx) is important during the Iron Age and the Roman period and undergoes a significant decline beginning with the Middle Ages. However, some minor and localized charcoal peaks occurred during and after the transition to the feudal system (Fig. 7). The largest of these peaks took place at the end of the deforestation trend and coincided with a minor HFDE (ca. $950 \mathrm{CE}$ ). The other charcoal peaks of lower intensity were also close to two LFDEs (ca. $1100 \mathrm{CE}$ and ca. $1200 \mathrm{CE}$ ) that occurred during the forest recovery phase (Fig. 7). Considering that at least 13 minor deforestation events have been identified during the Middle Ages, it seems that most of them were due to extractive practices. Beyond $1200 \mathrm{CE}$, fire incidence was almost negligible until the end of the sequence (Fig. 5).

Climate could have also played a role in Medieval forest dynamics. The maximum deforestation occurred during the MCA, characterized by warmer and drier climates, which may have favored the occurrence of fire (note that the three charcoal peaks mentioned before occurred during the MCA) and the increase in human activities around the lake by upward migration from lowlands due to favorable climates. Therefore, these three factors, warm/dry climates, humans and fire, could have acted synergistically to magnify deforestation trends. Subsequent forest recovery, especially from the end of fire peaks onward, may have been favored by the LIA cold climates and depopulation that occurred during the ending Medieval crisis (Fig. 7).

\subsection{Modern Age (1488-1789 CE)}

The Middle Ages and the political independence of the Pallars county ended with the Pallars War, in which the region was conquered by the Castille-Aragon crown and transformed into the 


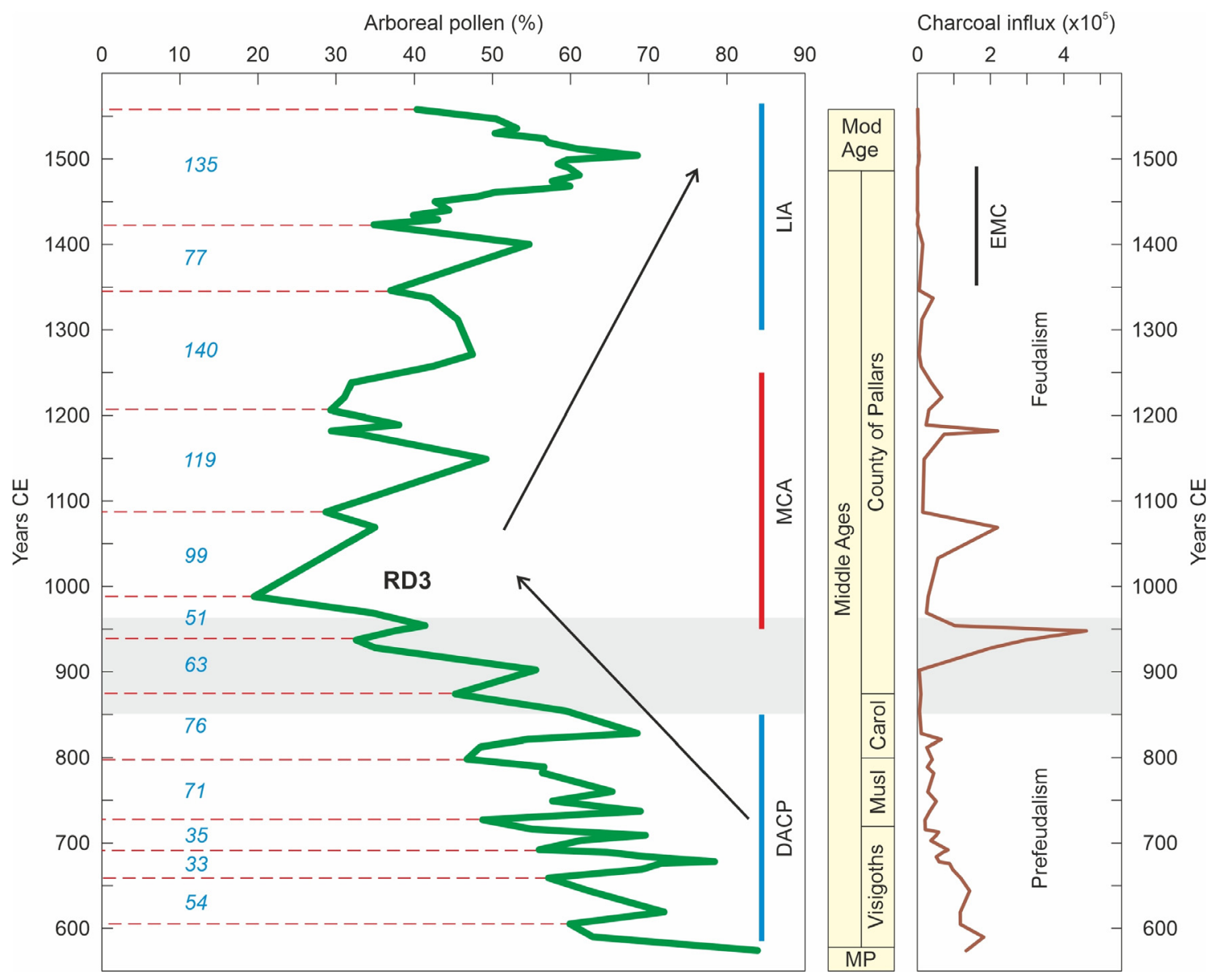

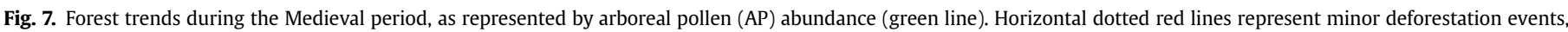

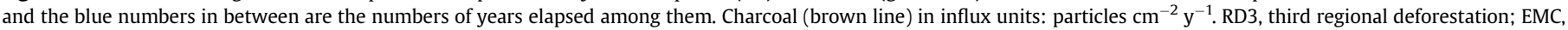

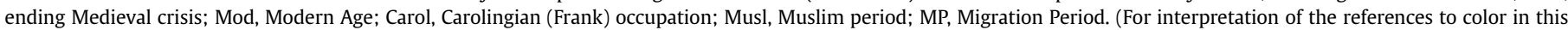
figure legend, the reader is referred to the Web version of this article.)

Marquisate of Pallars, under monarchic dominion (Bringué, 2005). From a paleoecological point of view, this period was rather stable, and no significant vegetation or landscape shifts have been recorded in the catchment or in its surrounding areas (Fig. 5). Regional forests experienced a relevant reduction, which is provisionally denoted RD4, but this may be an artifact, as will be discussed later. Inside the catchment, the main difference from late-Medieval times is the recovery of Cannabis pollen, coeval with the decline of grass meadows and weeds (Artemisia, Plantago), whereas Olea and the secondary colonizers (Buxus, Juniperus, Betula) maintained the increase initiated during the ending Medieval crisis. Also noteworthy is the decline in HREs and the persistence of very low values of SY. Climatically, the Modern Age corresponded to the second half of the LIA (Fig. 6).

The apparent vegetation and landscape continuity of the Montcortès area contrasts with the significant socioeconomic changes experienced by the Pallars region during the Modern Age. Spectacular demographic growth took place after the ending Medieval crisis, which doubled the population numbers in barely two decades (Bringué, 2005). A significant portion of the new immigrants came from France. Although extensive cultivation (cereals, olive, vineyards) was still practiced, progressive replacement of crops by pastures occurred, especially in the highlands, which supported heavy grazing pressure by large sheep flocks in permanent horizontal transhumance. Forest exploitation for wood and charcoal also increased, mainly to maintain the expanding iron industry, which experienced significant technical improvements and used hydraulic power (Fig. S5; Supplementary material). In the Montcortès catchment, however, the dramatic increase in hemp cultivation/retting was the only relevant observation and, apparently, the main economic activity around the lake during the Modern Age. The pollen record suggests that the importance of this industry during those times is difficult to explain only in terms of local consumption (Rull et al., 2011).

A fundamental historical event in this discussion is the European-American contact that occurred in $1492 \mathrm{CE}$, which was funded by the Castille monarchy. This discovery fostered the outstanding development of the Spanish Royal Navy, which required a permanent and abundant supply of hemp fiber for the manufacture of ropes and sails. Catalonia was among the most important regions for hemp production in both quantity and quality, particularly the Pallars region (Trapote et al., 2018b). Lake Montcortès is especially well suited for hemp retting due to the local bacterial community, which is able to detach the cuticular fibers from the plant stems in a spontaneous way (Rull and VegasVilarrúbia, 2014). In this case, hemp cultivation around Lake Montcortès is unlikely, as the maximum hemp pollen occurred during the LIA, when climates were colder than at present and significantly colder than in Medieval times, especially during the MCA, when cultivation could have been possible. Historical documents report frequent hemp cultivation in some surrounding lowland (500-800 m elevation) villages during the Modern Age 
(Madoz, 1845). Therefore, the most likely explanation is that the Modern-Age hemp pollen record of Lake Montcortès is due to retting practices rather than to local cultivation. One of the consequences of hemp retting is the change in physicochemical water properties, especially nutrient enrichment and eventual eutrophication (Anderson, 1995). In Lake Montcortès, this could explain the increases in aquatic plants including littoral vegetation (Typha and Cyperaceae) and planktonic algae such as Pediastrum (Fig. 5).

Two historical events could have favored the development of the hemp industry around the Montcortès area. First, the opening in 1687 CE of a new road through the southern Montsec Range, one of the orographic accidents responsible for the historical isolation of the Pallars region, facilitated commercial communications with the Catalonian lowlands and coasts situated to the south (Bringué, 2005). Second, the same 1617 CE decree that established the absolutist monarchy in Spain (Fig. S5; Supplementary Material) also opened trade with American colonies to Catalonia and other regions that previously had not had access to such activities. In the pollen diagram (Fig. 5), an increase in the hemp curve is manifested after these dates. In the 18th century, hemp cultivation was mandatory by royal decree in all Spanish lands suitable for this crop, which resulted in a production peak at the end of the Modern Age (1770 CE) (Sanz, 1995).

\subsection{Contemporary times (1789 CE to present)}

The last centuries may be subdivided into two main paleoecological phases separated by the Industrial Revolution, which took place in Catalonia between 1832 and 1935 CE (Fig. S5; Supplementary Material). The preindustrial phase was characterized by a situation similar to that in the Modern Age that represents the maximum of the hemp industry. The postindustrial phase represents the end of hemp retting in Montcortès and the expansion of regional forests and olive crops (Fig. 5). The interval corresponding to the Catalan industrial revolution is characterized by relevant peaks in HREs and SY. Climatically, the contemporary times coincide with the end of the LIA and the ongoing GW (Fig. 6).

From a socioeconomic point of view, the preindustrial Pallars was characterized by a subsistence economic system where most production was intended for local consumption and only a few products, notably salt and oil, were in surplus and available for external commercialization. Although not mentioned in the available historical documentation, the Montcortès catchment was still dedicated mainly to hemp retting, an activity that attained its maximum in this phase, coinciding with the acme of commerce with America and the maximum development of the naval industry in Catalonia (Delgado, 1994). The situation changed when, in 1834 $\mathrm{CE}$, the Spanish royal navy was dismantled and the demand for hemp fiber plummeted. This coincided with the maximum and further decline of hemp retting in Lake Montcortès (Fig. 5). The appearance of new materials such as cotton and synthetic fibers, as well as manufactured fabrics, imported from other countries in Europe and overseas also contributed to the hemp decline (Trapote et al., 2018b).

The postindustrial phase was characterized by two demographic crises that significantly reduced the Pallars population. The first of the crises has been attributed to the combination of the arrival of the phylloxera vineyard plague (1879 CE) and several years of unfavorable climates and bad harvests (1893-1896 CE). The second crisis (1960-1980 CE) was caused by the emigration of the Pallars population to industrial areas. Overall, the Pallars region lost almost $60 \%$ of its population between 1857 and 1991 (Sabartés, 1993). Between these two crises, some demographic recovery occurred thanks to the hydroelectrical development of the region (Fig. S5; Supplementary Material). The recovery of regional forests mentioned above could be linked to the decrease in farming and herding activities. At present, the main economic activity in the Pallars region is tourism.

A last observation regarding hemp seems opportune. The scarce/null presence of hemp pollen during most of the 20th century was reversed in recent decades, from the 1980s onwards, when it experienced a relevant increase (Fig. 5). This increase is still in force, as demonstrated by the modern analog study using submerged traps mentioned in the methods section. Indeed, presentday pollen assemblages that reach Lake Montcortès sediments have variable amounts of Cannabis pollen, between $10 \%$ and $40 \%$ of the pollen sum, with maxima during fall/winter (Rull et al., 2017). No hemp crops have been observed in the surroundings, and local people do not know where this plant could be cultivated in the area. The significant statistical associations of Cannabis pollen abundance with wind speed and direction suggest that longdistance wind transport would be involved, as demonstrated in other aerobiological studies (Cabezudo et al., 1997). However, the source of hemp pollen sedimented in Montcortès remains unknown.

\subsection{Cannabis retting and forest dynamics}

Accepting that hemp retting and not local cultivation is the most reliable source for the abundant Cannabis pollen during modern and contemporary times has important implications for the construction and interpretation of the pollen diagram. If Cannabis was not part of the local and regional Montcortès vegetation but was transported there by humans, then its pollen should be excluded from the pollen sum. Otherwise, the percentages of other pollen types could be artificially distorted. Especially significant is the forest reduction previously called RD4, which could be an artifact due to the high abundance of Cannabis pollen. When this pollen is excluded from the pollen sum, the RD4 event becomes significantly less intense, although it does not disappear (Fig. 8). During this interval, the resolution of the forest dynamics reconstruction is subdecadal (ca. $6 \mathrm{yr} / \mathrm{sample}$, on average), which doubles the resolution of the Medieval reconstruction (Fig. 7). The recurrence times of minor deforestation events above and below RD4 are ca. $34 \mathrm{yr}$ and ca. $37 \mathrm{yr}$, respectively, which are lower than those in Medieval times. In this case, the process of forest reduction is different from that in the Middle Ages (Fig. 7), as the minor deforestation events, although more frequent, are less intense and insufficient to produce a cumulative effect triggering a definite and maintained deforestation trend. Instead, shorter clearing and recovery trends led to a less intense deforestation of approximately $50 \%$ reduction in forest tree pollen (compared with the maximum of $70-80 \%$ in the Middle Ages; Fig. 7), on average, between ca. 1710 and 1860 CE. From this point, a continuous trend of forest recovery is observed during contemporary times.

Fire incidence was also important but significantly lower than that in Medieval times, when charcoal concentrations were two orders of magnitude higher (Fig. 7). This, together with the above deforestation numbers, as deduced from pollen trends, suggests that during the Modern Age, forests would have been cleared only partially and/or in a very localized manner. This would be consistent with the profound shift in land property and land-use patterns that occurred after the dismantling of the feudal system, where a small group of nobles owned the whole territory, which was exploited following extensive criteria (Marugan and Oliver, 2005). Contrarily, during the Modern Age, the territory was much more subdivided, and the concepts of private and communal property appeared, which led to a more intensive and diversified production system (Bringué, 2005). In the case of forests, extracted wood was usually submitted to renting or licensing for fixed amounts during a 


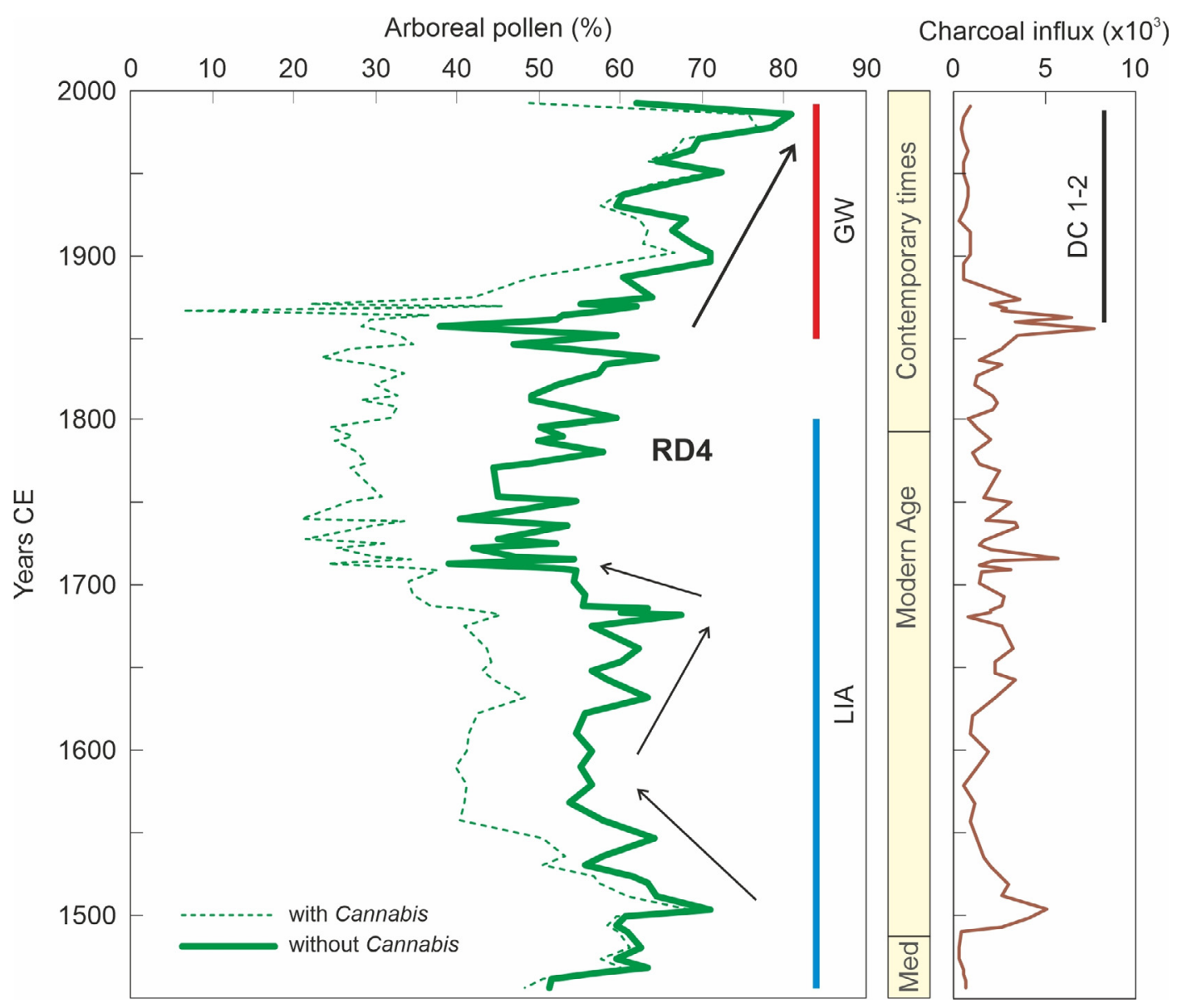

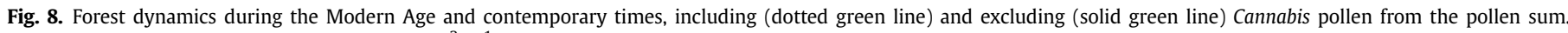

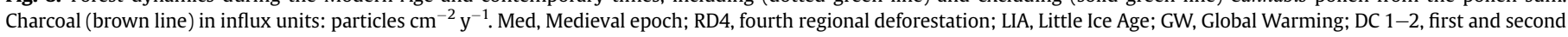
demographic crises. (For interpretation of the references to color in this figure legend, the reader is referred to the Web version of this article.)

given period of time. This partial and transitory way of exploitation would be consistent with the patterns of deforestation and fire incidence observed during the Modern Age (Fig. 8). Forest recovery occurred during contemporary times, from ca. $1860 \mathrm{CE}$, coinciding with the latest fire peak and the onset of the first and second most recent demographic crises of the Pallars region (Sabartés, 1993).

Regarding climate, it should be noted that deforestation occurred during the LIA, which could have contributed to relaxing the frequency and intensity of human activities around the lake. Forest recovery took place during the ongoing GW, which could have reinforced the effect of the depopulation of the Pallars region and a significant decline in fire. Once more, climatic and cultural drivers of ecological change seem to have acted in combination to generate and/or reinforce vegetation and landscape shifts.

\section{The Montcortès paleoecological record in a wider context}

\subsection{The Pyrenees and the Iberian Peninsula}

On the Iberian Peninsula, there are no continuous, highresolution paleovegetation records for the Late Holocene comparable to those of Montcortès (Carrión, 2012 and literature therein). On the one hand, the known varved records are significantly shorter and/or discontinuous, as mentioned in the introduction (Zolitschka et al., 2015). On the other hand, the few palynological studies on these varved records are of significantly lower resolution, typically centennial (Burjachs, 1996; Julià et al., 1998; Martín-
Puertas et al., 2008; Romero-Viana et al., 2008; Corella et al., 2013) (Table 2). Therefore, comparisons with Iberian palynological records of the last 3000 years should be performed using nonvarved sediments.

Most of the $>20$ palynological records from the southern-central Pyrenees are from high-altitude lakes and peat bogs situated in subalpine and alpine environments above a $1600 \mathrm{~m}$ elevation (González-Sampériz et al., 2017, 2019, 2019; Rull and VegasVilarrúbia, 2021). These localities are different from Lake Montcortès in both climatic and biotic features as a consequence of elevation, Mediterranean influence and biogeographic features. Only two records have been retrieved in the montane and submontane belts, at elevations similar to Montcortès: the Prats de Vila $(1150 \mathrm{~m})$ and the Estanya $(670 \mathrm{~m})$ records (Riera et al., 2004; Pèlachs et al., 2009; González-Sampériz et al., 2017). However, these records lack long and continuous varved sequences similar to those of Lake Montcortès and have been analyzed at lower (centennial to millennial) resolutions.

In terms of vegetation, the Montcortès record is more similar to the Estanya reconstruction, likely due to the Mediterranean influence on both, which is manifested mainly in the common presence of Quercus in regional and local forests. The Prats de Vila sequence, despite its elevation being more similar to that of Montcortès, has more Eurosiberian influence, and the major forest components are Abies, Alnus, Corylus and Fagus, while Quercus is absent (Fig. 9). Another aspect in which Montcortès and Estanya resemble each other is the development of the hemp industry. There is a 
Table 2

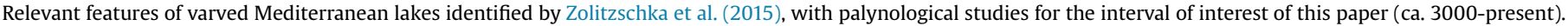
NA, not available.

\begin{tabular}{|c|c|c|c|c|c|c|c|c|}
\hline Lake & $\begin{array}{l}\text { Elevation } \\
(\mathrm{m})\end{array}$ & Varved record & $\begin{array}{l}\text { Varve } \\
\text { years }\end{array}$ & $\begin{array}{l}\text { Varve } \\
\text { thickness } \\
(\mathrm{mm})\end{array}$ & Chronology & Palynology & Resolution & References \\
\hline Nar (Turkey) & 1363 & $300-2000 \mathrm{CE}$ & 1700 & 2.2 & Absolute & $\begin{array}{l}\text { 300-2000 CE; } 13,700 \\
\text { BP-present }\end{array}$ & $\begin{array}{l}\text { Bidecadal to } \\
\text { bicentennial }\end{array}$ & $\begin{array}{l}\text { Jones et al. (2006); England et al. (2008); } \\
\text { Roberts et al. (2016) }\end{array}$ \\
\hline $\begin{array}{l}\text { Montcortès } \\
\text { (Spain) }\end{array}$ & 1027 & 2699-present & 2699 & 2.4 & Absolute & 3000 BP-present & Bidecadal & This paper \\
\hline La Cruz (Spain) & 1000 & 1579-2002 CE & 423 & 0.95 & Absolute & $\sim 520$ CE-present & Multidecadal & $\begin{array}{l}\text { Burjachs (1996); Julià et al. (1998); } \\
\text { Romero-Viana et al. (2008) }\end{array}$ \\
\hline Arreo (Spain) & 655 & 1952-1998 CE & 46 & 1.1 & Floating & $0-2000 \mathrm{CE}$ & Multidecadal & Corella et al. (2011b, 2013) \\
\hline $\begin{array}{l}\text { Avigliana } \\
\text { (Italy) }\end{array}$ & 353 & $1935-2000 \mathrm{CE}$ & 65 & 3 & Absolute & $1820-2000 \mathrm{CE}$ & Subdecadal & Finsinger et al. (2006) \\
\hline Zóñar (Spain) & 300 & $\begin{array}{l}\sim 2530-2100 \mathrm{BP} ; \sim 1940 \\
-1910 \text { ВР } \sim 1780-1600 \text { ВР }\end{array}$ & 637 & $\sim 1$ & Floating & 3400 BP-present & Centennial & Martín-Puertas et al. $(2008,2009)$ \\
\hline Albano (Italy) & 293 & $1944-1990 \mathrm{CE}$ & 46 & 2.6 & Absolute & 14,000 BP-present & Bicentennial & Lami et al. (1994); Mercuri et al. (2002) \\
\hline $\begin{array}{l}\text { San Puoto } \\
\quad \text { (Italy) }\end{array}$ & 2 & 1925-1995 CE & 70 & NA & Absolute & NA & NA & Alvisi and Dinelli (2002) \\
\hline $\begin{array}{l}\text { Butrint } \\
\text { (Albania) }\end{array}$ & 0 & 1741 CE-present & 259 & 5 & Absolute & $4370 \mathrm{BP}-2000 \mathrm{CE}$ & Bicentennial & $\begin{array}{l}\text { Ariztegui et al. (2010); Morellón et al. } \\
\text { (2016) }\end{array}$ \\
\hline $\begin{array}{l}\text { Dead Sea } \\
\text { (Jordania/ } \\
\text { Israel) }\end{array}$ & -423 & $\begin{array}{l}140 \mathrm{BC}-1408 \mathrm{CE} \text { (minor } \\
\text { gaps) }\end{array}$ & 1500 & 0.5 & Floating & $\begin{array}{l}2000 \text { BCE-1516 CE; } \\
\sim 2500-500 \text { BCE }\end{array}$ & Multidecadal & $\begin{array}{l}\text { Migowski et al. (2004); Neumann et al. } \\
\text { (2007); Langgut et al., 2014) }\end{array}$ \\
\hline
\end{tabular}

remarkable chronological coincidence in the introduction of hemp (early Middle Ages) and the maximum development of this industry (second half of the Modern Age), in both localities (Fig. 9). The great development of this industry during the Modern Age is likely a manifestation of the political mandate of providing materials for the Spanish royal navy already discussed. The main difference is that in Estanya, hemp cultivation and retting have been documented historically (Riera et al., 2004, 2006), whereas in Montcortès, although there is no information on these particular practices, cultivation has been considered less likely due to the higher elevation (Rull et al., 2011; Rull and Vegas-Vilarrúbia, 2014; Scussolini et al., 2011; Trapote et al., 2018b).

Looking at deforestation trends, the three sections coincide in terms of large-scale forest clearing episodes during the Middle Ages followed by events of forest recovery. However, in Estanya and Prats de Vila sequences, the level of resolution is lower than in Montcortès, which hinders more detailed comparisons. Regarding land use patterns, Montcortès seems more similar to Prats de Vila, as cereal cultivation, grazing and forest management have been the main activities (Pèlachs et al., 2009). Evidence for typical Mediterranean crops such as vineyards and olive groves occurs only in Estanya, likely due to its lower elevation and higher Mediterranean influence. The three sites also differ in the timing of landscape anthropization, which in Estanya goes back to the Late Bronze Age (González-Sampériz et al., 2017) but in Montcortès has been recorded in the early Iron Age (Rull et al., 2021) and in Prats de Vila was documented for the Iron Age/Roman transition (Pèlachs et al., 2009). However, it should be stressed that, in the case of Montcortès and Prats de Vila, these are minimum anthropization ages, as older Bronze Age sediments are still unavailable in both localities.

Large chronological differences in landscape anthropization are common in montane and submontane areas of the Iberian Peninsula under Mediterranean influence. A recent compilation across the whole peninsula reported a wide range of anthropization times, between the early Bronze Age and the Middle Ages, with remarkable geographical heterogeneity and no evident spatial patterns (Fig. 10). This was attributed to the occurrence of heterogeneous cultural patterns in both time and space across montane to submontane vegetation belts of the Iberian mountains, and the development of local studies focused on particular mountain ranges has been recommended to evaluate the possibility of chronoelevational anthropization patterns (Rull et al., 2021). A pilot study of this type exists for the southern-central Pyrenees that may serve as an example. A set of lake and peat bog sites with suitable palynological reconstructions ranging from submontane to alpine belts were found to be anthropized between the Bronze Age (submontane) and the Middle Ages (subalpine/alpine), following a statistically significant trend of approximately $40 \mathrm{~m}$ of upward migration per century (Fig. 11). These results were considered preliminary and should be confirmed with future studies, especially at the lower mountain elevations, where data are still scarce (Rull and Vegas-Vilarrúbia, 2021).

No similar studies are available for the northern Pyrenean slope. A paleoecological review is available for southern France that includes localities from the northern Pyrenean side under Mediterranean influence, ranging from a ca. 700 to ca. $2200 \mathrm{~m}$ elevation (Berger et al., 2019). However, this dataset was studied globally, and a more detailed analysis of anthropization thresholds with elevation was not carried out. It would be interesting to perform a chronoelevational gradient analysis similar to that developed for the southern side to compare spatiotemporal anthropization patterns on both sides of the Pyrenees.

Other studies exist for non-Mediterranean mountain areas of the Iberian Peninsula that are under the influence of Atlantic climates. These areas are out of the scope of this paper, which is focused on the Mediterranean region. However, a recent compilation of low to mid-elevation localities of the Cantabrian range is worth to be mentioned, as landscape anthropization times range from the Bronze Age to historical times (Pérez-Díaz et al., 2018). 


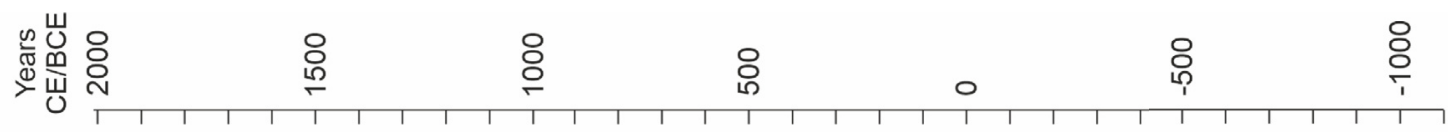

\begin{tabular}{|c|c|c|c|c|c|}
\hline \multirow{2}{*}{ 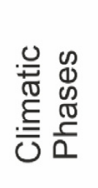 } & & & $\stackrel{\forall I 7 \forall 7}{\longmapsto}$ & \multicolumn{2}{|c|}{$\begin{array}{l}\text { po!ıəd p!unh } \\
\text { ueuoy-ue!ıəql }\end{array}$} \\
\hline & әదิ & $\begin{array}{l}\text { Rןemour } \\
\text { u!!O pəW }\end{array}$ & 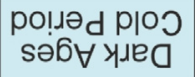 & $\begin{array}{l}\text { po!ləd mieM } \\
\text { uewoy }\end{array}$ & 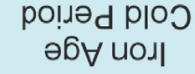 \\
\hline
\end{tabular}

\begin{tabular}{|c|c|c|c|c|c|c|c|c|c|c|}
\hline \multirow{2}{*}{ 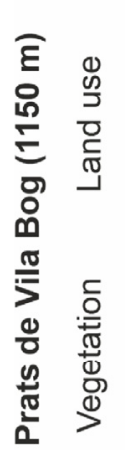 } & \multicolumn{2}{|c|}{ 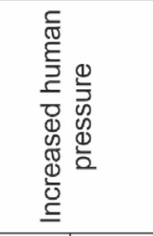 } & 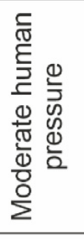 & 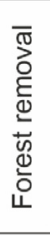 & 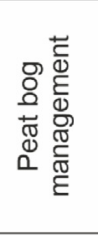 & 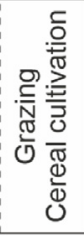 & 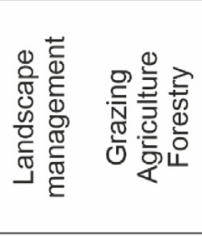 & 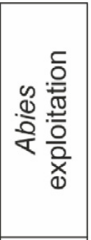 & & \\
\hline & 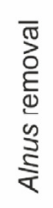 & 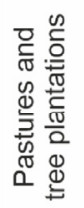 & 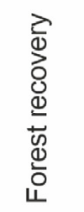 & & 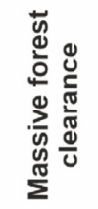 & & 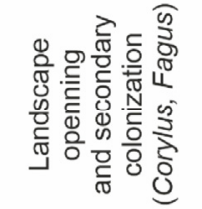 & 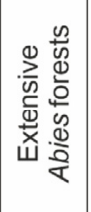 & & \\
\hline
\end{tabular}

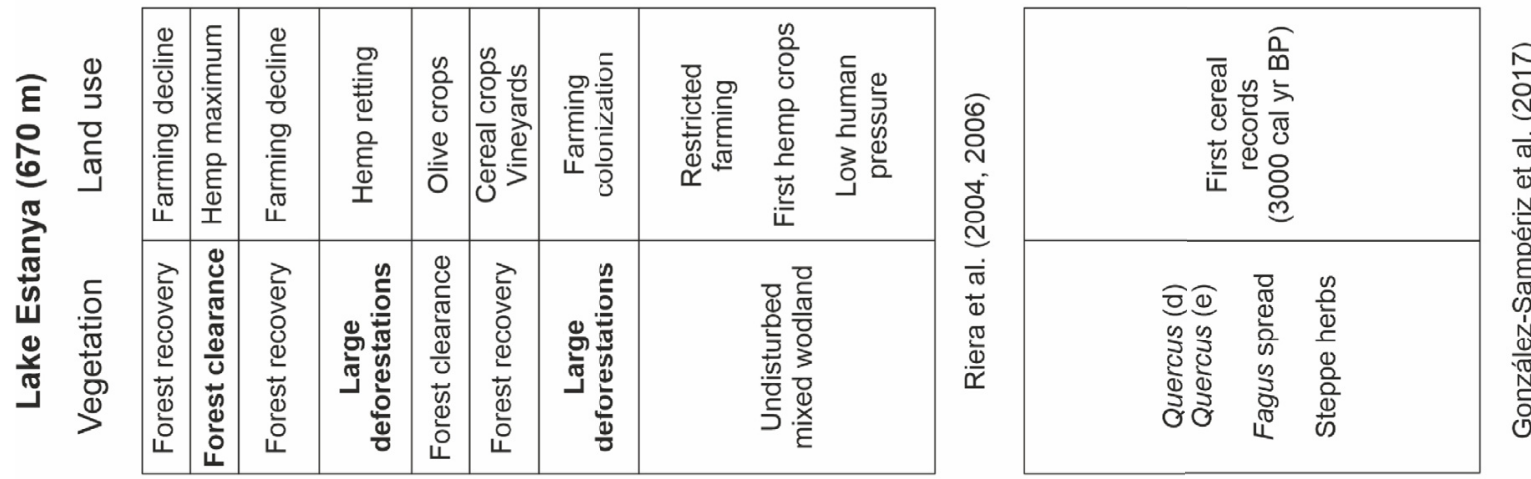

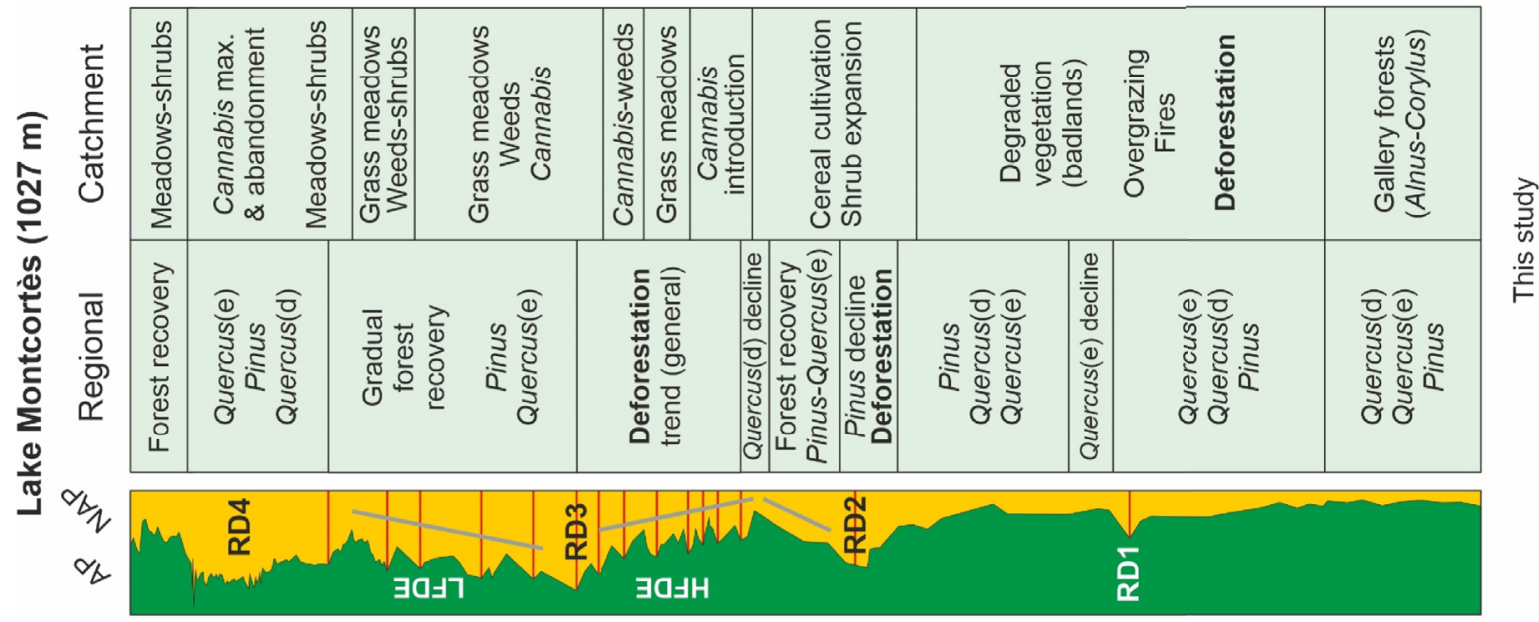

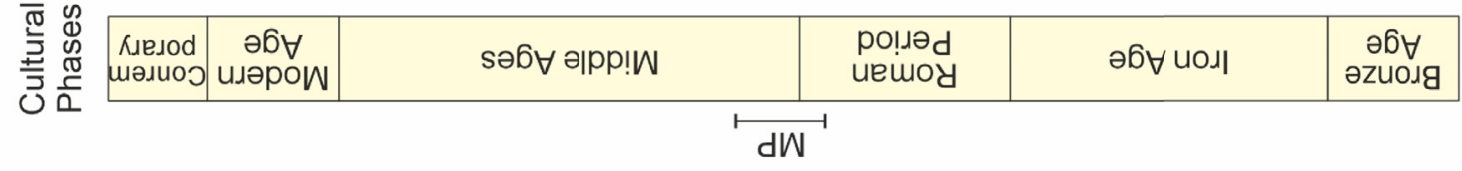

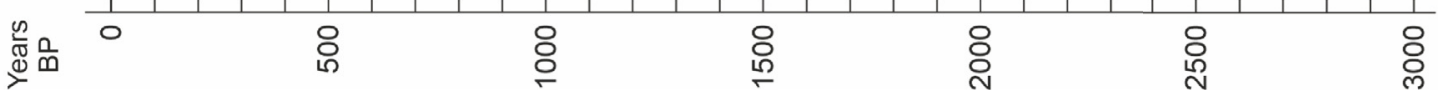


This suggests that a metaanalysis of the whole Iberian Peninsula considering anthropization times in relation to elevation, bioclimatic and cultural features would be very interesting. For this, it would be necessary to develop an exhaustive database, which could be based on the compilation by Carrión (2012) and its future updates.

\subsection{The mediterranean region}

This section attempts to compare the Montcortès paleovegetation reconstructions with others developed for sediments from Mediterranean lakes with varved sediments, using the compilation of Zolitszchka et al. (2015). It should be stressed that a long-distance comparison of paleovegetation records, even within the same biome (in this case, the Mediterranean), may be problematic because of environmental, biogeographical and cultural disparities among the regions studied. According to the compilation by Zolitszhka et al. (2015), 10 Mediterranean lakes hold varved records of variable nature, thickness and extension. These lakes are depicted in Fig. 12, and their main features are displayed in Table 2. Interestingly, only three lakes (Nar, Montcortès and La Cruz) are above a $1000 \mathrm{~m}$ elevation and may be considered montane lakes, whereas the others are in lowlands, with three of them (San Puoto, Butrint and Dead Sea) in littoral or nearly littoral environments. According to the original study, only three of these lakes (Dead Sea, Montcortès and Nar) have long records of $1500 \mathrm{yr}$ or more, whereas the other seven have records of ca. $650 \mathrm{yr}$ or less, with four records of $70 \mathrm{yr}$ or less. Seven records have absolute chronologies, and three (Dead Sea, Arreo and Zóñar) have floating varve chronologies. Further studies on some of these lakes extended these chronologies. The combination of varve counting and U/Th dating allowed extending the laminated record of Lake Nar to 14,000 yr BP, with some discontinuities (Roberts et al., 2016). However, no new dating by varve counting is provided beyond the already known $1700 \mathrm{yr}$ BP previously dated by Jones et al. (2006). In Lake Montcortès, absolute varve chronology was recently extended to $2700 \mathrm{yr}$ BP (Corella et al., 2016, 2019). Therefore, this lake holds the longest continuous and absolutely dated varved record of the whole Mediterranean region.

Most of these Mediterranean varved records have been studied palynologically, but as in the case of Montcortès, it has not been possible to reach an annual resolution due to the thinness of the varves, which ranges from $\sim 1$ to $5 \mathrm{~mm}$ (Table 2). The resolution of these paleoecological reconstructions varies from bicentennial to subdecadal, and the two longest records mentioned before for the eastern (Nar) and western (Montcortès) Mediterranean regions have been studied at a bidecadal resolution, on average. Fig. 13 compares the intervals dated by varve counting and the intervals studied palynologically (and their resolutions) for the Mediterranean varved lakes with available information. Overall, the data from Fig. 13 confirm that the Montcortès record also has the longest pollen sequence studied at the highest resolution of the entire region for the last three millennia.

In summary, Lake Montcortès emerges as a unique highresolution record of vegetation and landscape shifts and their natural and anthropogenic drivers for the Mediterranean region during the last three millennia. This time period is important, as a recent global empirical assessment of archaeological evidence revealed that the planet was largely transformed by hunter- gatherers, farmers and pastoralists by 3000 years ago, which is considerably earlier than the dates commonly used by Earth scientists (Steffens et al., 2019). In the case of Montcortès, this is especially true, since the present work demonstrates that the full anthropic transformation of the lake catchment occurred during the Iron Age (ca. $2700 \mathrm{yr}$ BP), significantly earlier than the Middle Ages, which previously was the norm for the Pyrenees (GonzálezSampériz et al., 2017). Another global reconstruction of sedimentation rates in lakes shows that a significant proportion of Earth's surface began to undergo human-driven soil erosion as early as 4000 yr ago (Jenny et al., 2019). Sediments of this age are still unavailable in Lake Montcortès cores, but their existence has not been ruled out (Rull et al., 2021), and they are worth pursuing.

However, despite its exceptionality, the Montcortès record cannot represent the Mediterranean region by itself due to the heterogeneity of this region in climatic, biogeographic and cultural terms (Lionello, 2012; Moatti and Thiébault, 2016). A more representative approach would be to identify at least three varved records from the western, central and eastern Mediterranean with absolute varve dating and high-resolution palynological studies. Lake Montcortès seems to be better suited to represent the western side, whereas Lakes Butrint and Nar would be selected for the central and eastern areas, respectively. In Lake Nar, laminations are common until 4000 yr BP and earlier (Robets et al., 2016), although a full absolute chronology has not yet been published. In addition, paleoecological analyses are available at a resolution similar to that for Montcortès until $1700 \mathrm{yr}$ BP. Lake Butrint also has laminated facies until approximately 3500 cal yr BP (Morellón et al., 2016), which could be investigated in terms of varve chronology. Regarding pollen analyses, the resolution is still too low (multidecadal) but could be increased with additional sampling.

\section{Final remarks}

In addition to the numerous particular findings already discussed throughout the paper, it seems important to highlight the main general novelties introduced here in the study of Lake Montcortès, as a potential paleoecological reference section of the western-Mediterranean area. These novelties are:

Chronological coherency. Our study provides, for the first time, a complete paleoecological record of the last three millennia using a single and updated chronological model based on varve counting. This cannot be found in former papers about the lake, as some of them were based on different chronological models available by the time of their development. This introduces a major difference, mainly in chronological coherency and in the temporal correlations with climatic and anthropogenic drivers, which have a significant influence on the causal explanations of the observed vegetation trends.

Higher resolution. The resolution of the study is significantly higher than previous studies, reaching the bidecadal scale, in average, and the subdecadal scale in some historical phases, as for example the Middle Ages and the Modern Age. This is due to the overlapping of several core sections, resulting in higher sample density, as compared with previous studies, when each core was studied individually. In addition, new data have been used that were not present in former studies. The most significant are the analysis of non-pollen palynomorphs (NPPs), which has been extended to the whole section.

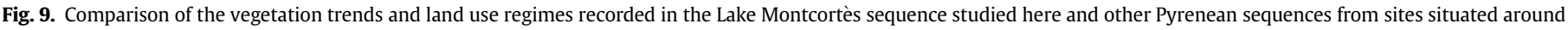

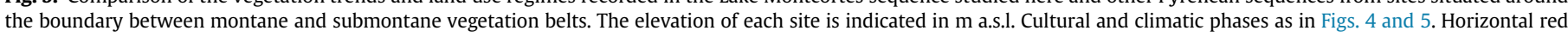

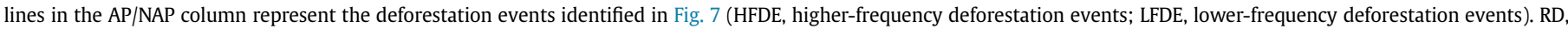

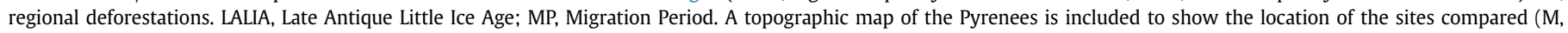
Montcortès; E, Estanya; V, Prats de Vila). (For interpretation of the references to color in this figure legend, the reader is referred to the Web version of this article.) 


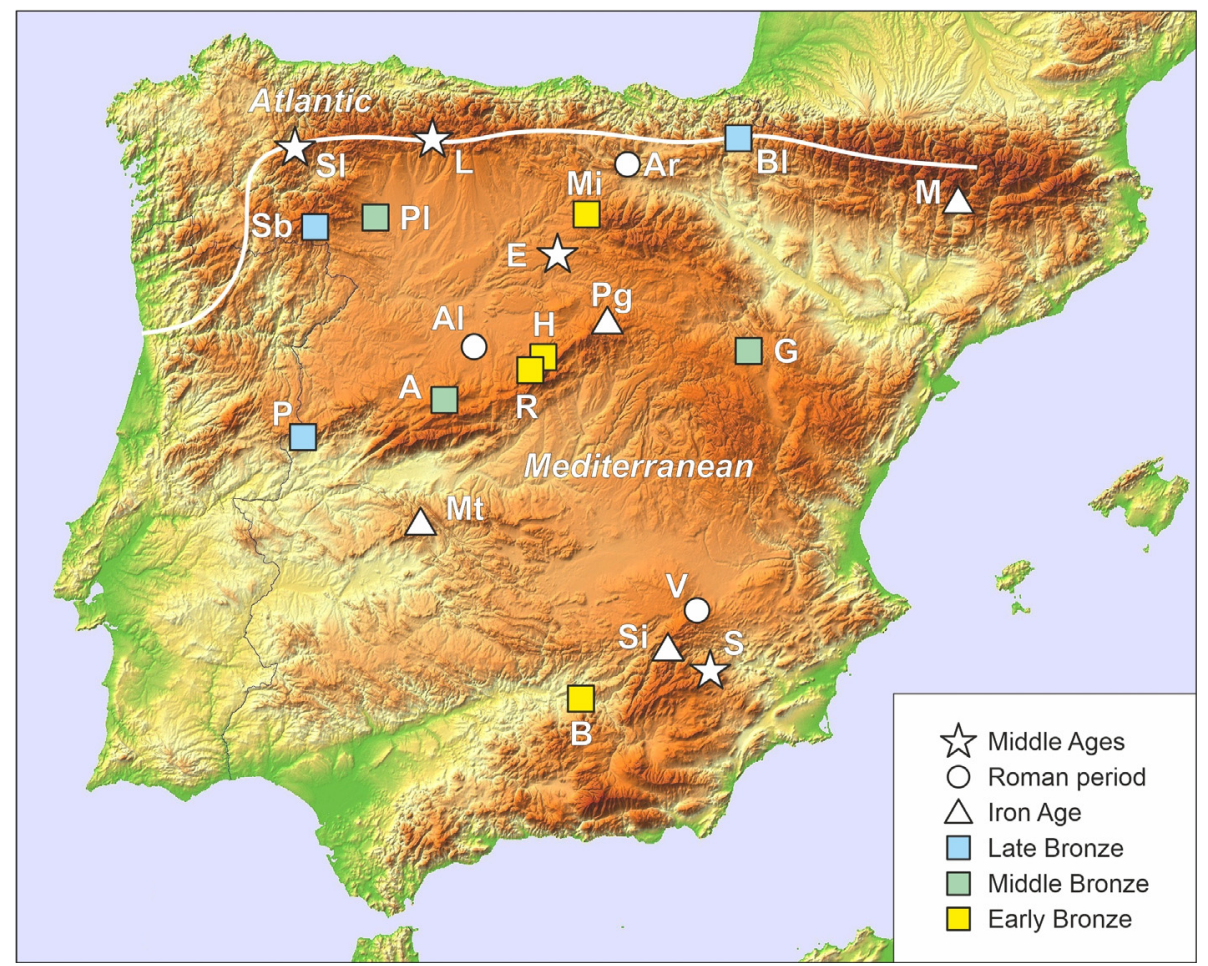

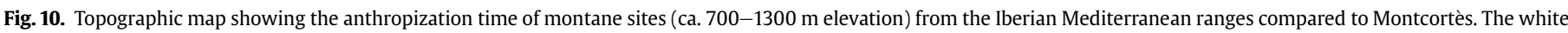

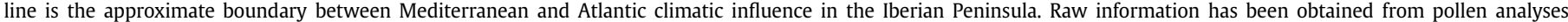

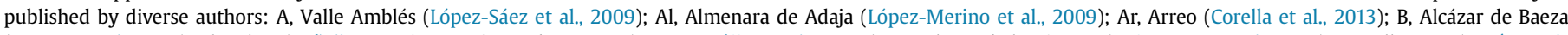

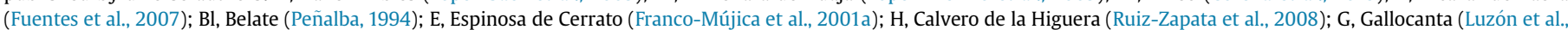

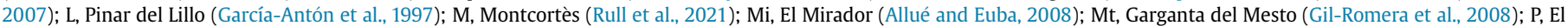

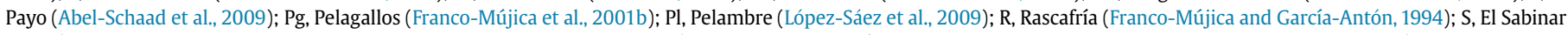

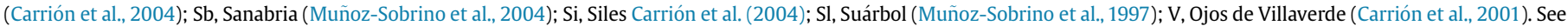
Rull et al. (2021) for more details.

Improved multiproxy approach. The use of non-palynological climatic and sedimentological proxies that provided independent evidence on climatic and environmental change, thus avoiding circularity. These proxies include speleothems, plankton-based transfer functions, heavy rainfall events, sediment yield, among others. These parameters, together with charcoal remains, NPPs and charcoal records, have provided the basis for multidisciplinary interpretations, which are absent in most previous partial studies. In this way, vegetation shifts could have been associated to natural or anthropogenic factors, or to combinations of them, with more reliability.

The chronological coherency, the higher resolution and the use of an improved multiproxy approach has provided new insights, concepts and interpretations, notably:
- The recurrent high-resolution (subdecadal) reconstruction of deforestation and regeneration trends during the Middle Ages and the Modern Age, in relation to climate and human management, as inferred from independent proxies and historical documentation.

- The intimate relationship between major vegetation shifts and cultural changes, whose main expression is the occurrence of four major deforestation events (R1 to R4) during the Iron Age, the Roman Period, the Middle Ages and the Modern Age.

- The detailed comparison between the Montcortès record and other Pyrenean records situated at similar elevations (Estanya, Prats de Vila), showing relevant differences according to their bioclimatic features (Atlantic or Mediterranean).

- The biome-wide comparison of the available Mediterranean records, which has led to the novel discovery that the 


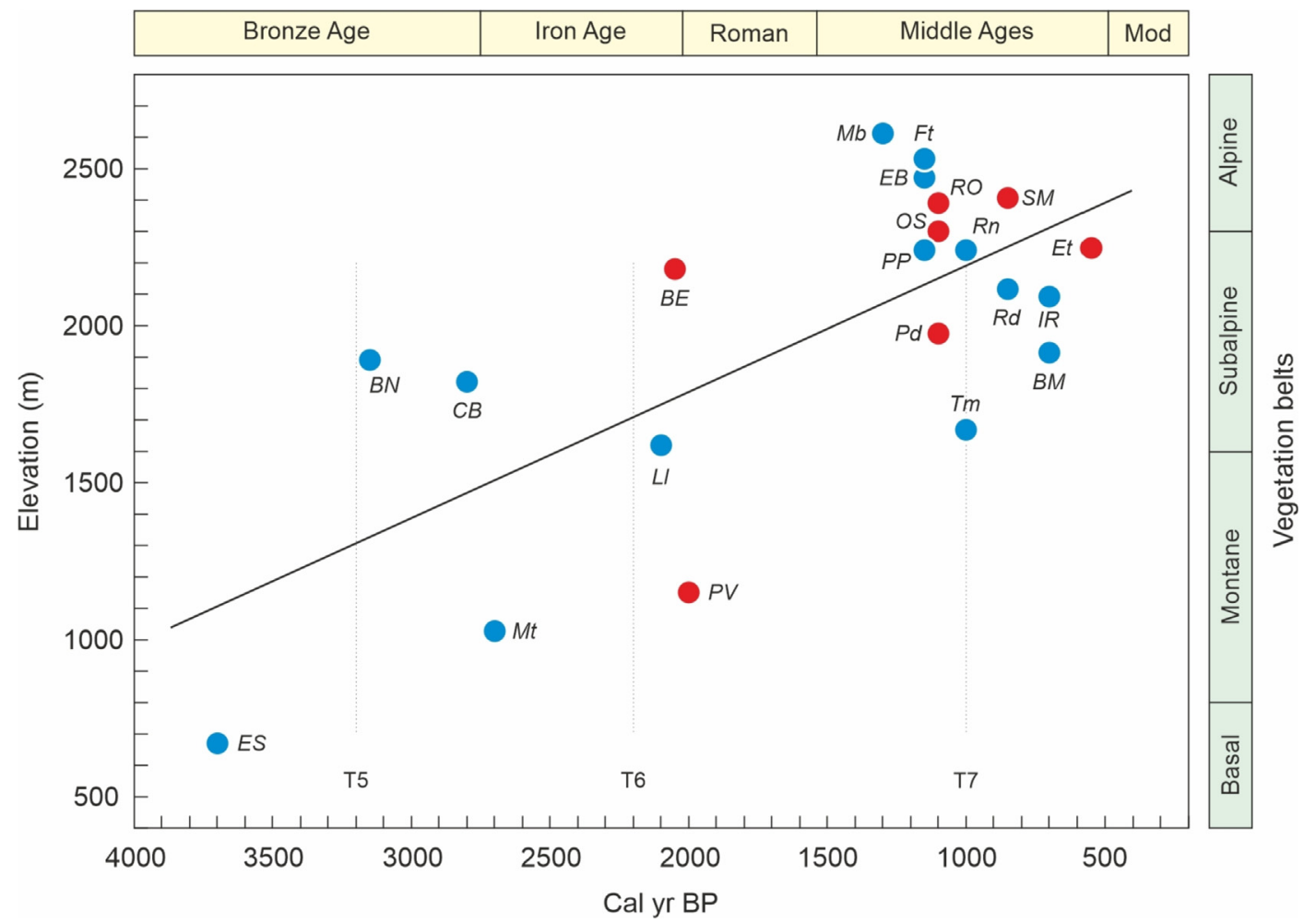

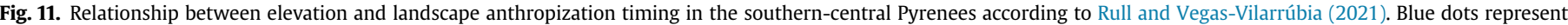

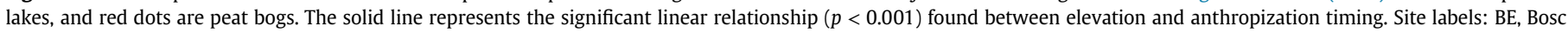

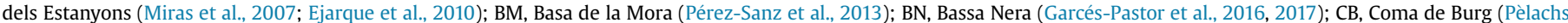

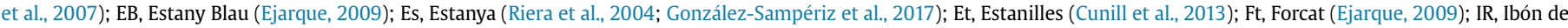

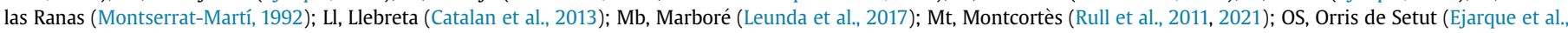

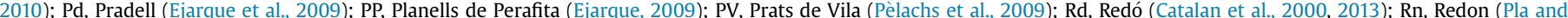

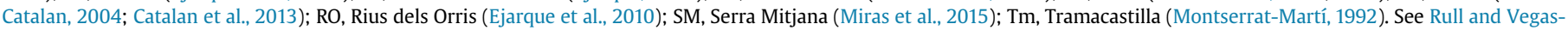
Vilarrúbia (2021) for more details. (For interpretation of the references to color in this figure legend, the reader is referred to the Web version of this article.)

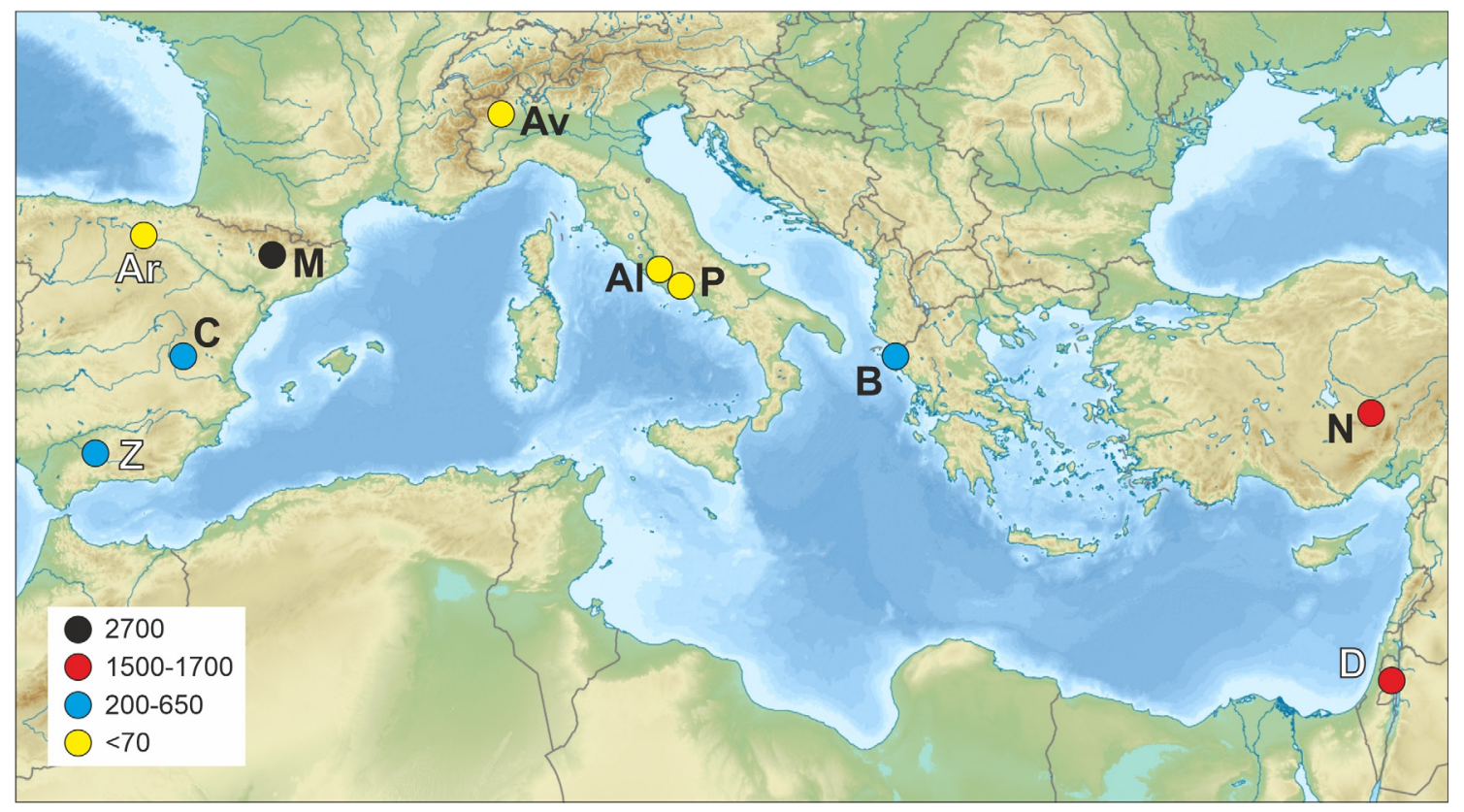

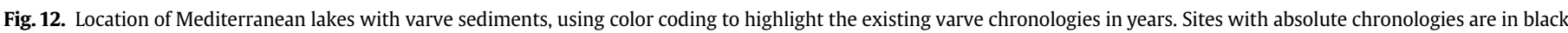

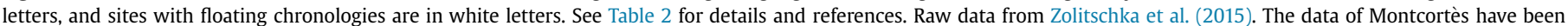

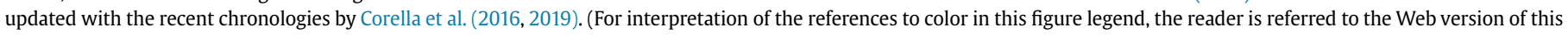
article.) 


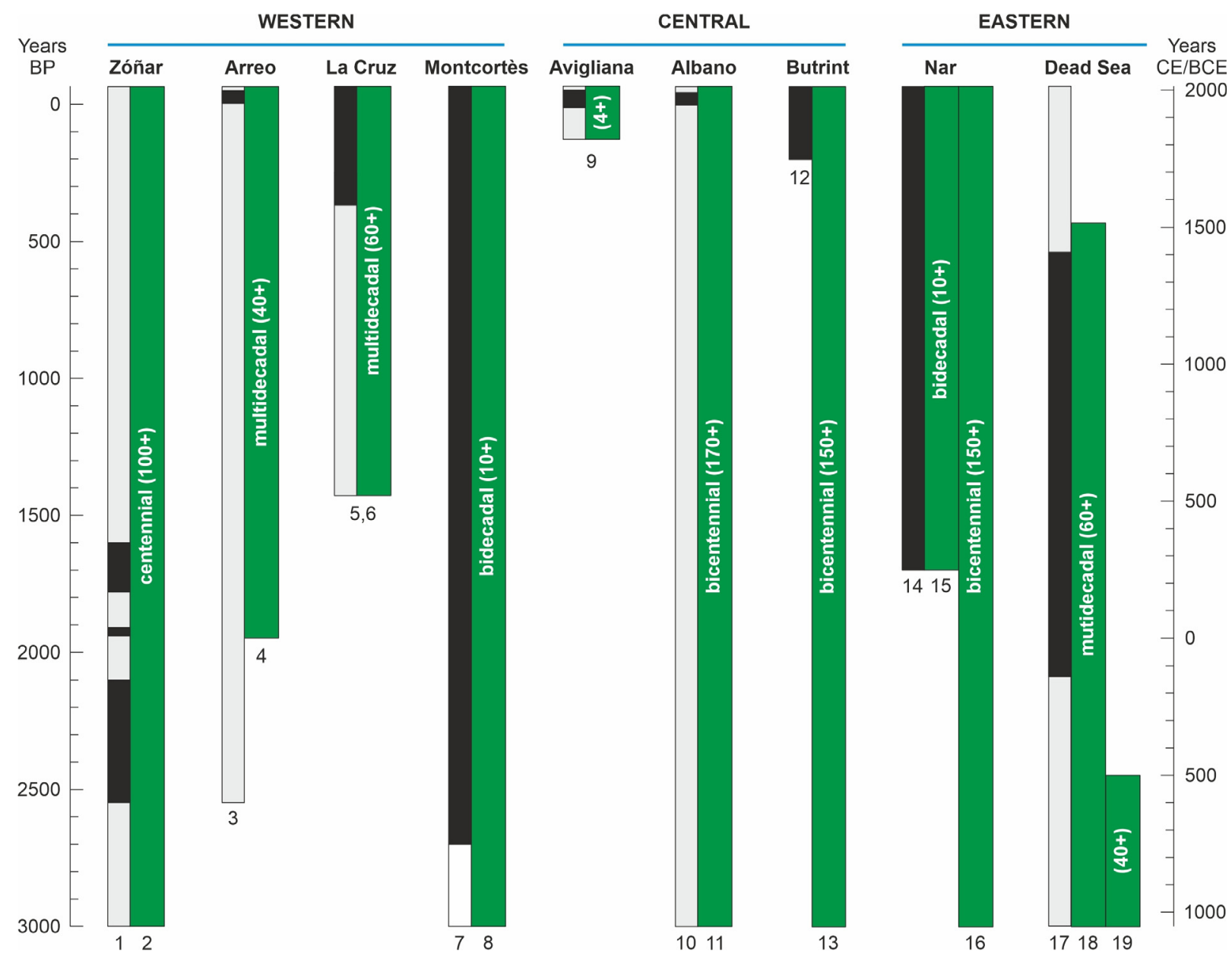

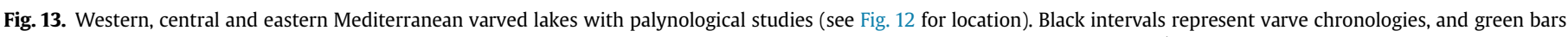

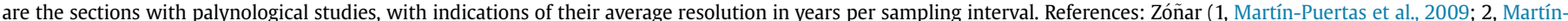

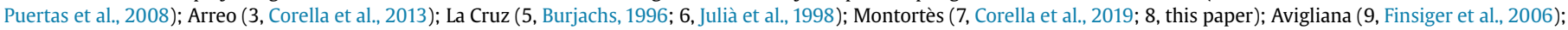

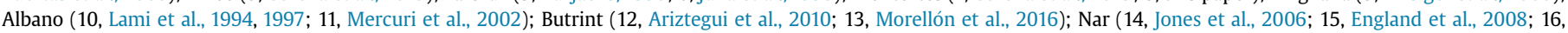

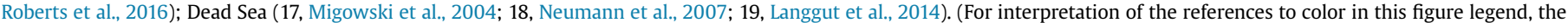
reader is referred to the Web version of this article.)

Montcortès record is the longest (ca. 3000 years) of the region with an absolute varve chronology and a high-resolution paleoecological reconstruction of the whole record.

None of these new findings would have been possible without the assembly of a single coherent paleoecological sequence based on the cores that were analyzed individually in former studies using different age-depth models, resolutions and selections of proxies. Therefore, the comprehensive paleoecological approach used here not only magnifies the paleoecological potential of the Montcortès section but also provides new insights and interpretations, which would be impossible to attain with merely the sum of parts.

\section{Author contributions}

VR: conceptualization, methodology, formal analysis, investigation, data curation, writing, visualization, and funding acquisition. TVV: investigation, resources, review \& editing, and funding acquisition; JPC: methodology, software, formal analysis, investigation, data curation, review \& editing, and visualization; EM: methodology, software, formal analysis, investigation, data curation review \& editing, and visualization; MCT: methodology, software, formal analysis, investigation, data curation, and review \& editing; BVG: investigation, resources, review \& editing, and funding acquisition.

\section{Declaration of competing interest}

The authors declare that they have no known competing financial interests or personal relationships that could have appeared to influence the work reported in this paper.

\section{Acknowledgments}

This work was funded by the Spanish Ministry of Science and Technology, projects RyC2003 to Valentí Rull, LIMNOCLIBER (REN 2003-09130-C02-02) and MEDLANT (CGL 2016-7215-R) to Blas Valero-Garcés; and the Spanish Ministry of Economy and Competitiveness, project MONT-500 (CGL 2012-3665 and CGL 2017-85682-R) to Teresa Vegas-Vilarrúbia. Fieldwork was conducted with the aid of Doug Shnurrenberger, Mark Shapley and Anders Noren (Limnological Research Center, USA); Penélope González-Sampériz and Ana Moreno (Pyrenean Institute of Ecology, Spain); Santiago Giralt and Núria Cañellas (Institute of Earth Sciences Jaume Almera, Spain), and Elisabet Safont and Sandra 
Garcés (University of Barcelona, Spain). Fieldwork permits were granted by the Territorial Service of the Department of Agriculture, Livestock, Fishing and Natural Environment of Catalonia (Barcelona). Samples were processed by Núria Cañellas (Laboratory of Paleoecology, Institute of Earth Sciences Jaume Almera). Climatic data were provided by Javier Sigró (University Rovira I Virgili). The collaboration of local entities and persons, notably the Council of Baix Pallars (Gerri de la Sal) and Xavier Figuera (Montcortès), was crucial for fieldwork development. Historical documentation was provided by the Pallars Sobirà District Archive (Sort). The authors acknowledge the comments of three anonymous reviewers.

\section{Appendix A. Supplementary data}

Supplementary data to this article can be found online at https://doi.org/10.1016/j.quascirev.2021.107128.

\section{References}

Abel-Schaad, D., Hernández Carretero, A.M., López-Sáez, J.A., et al., 2009. Evolución de la vegetación en la Sierra de Gata (Cáceres-Salamanca, España) durante el Holoceno Reciente. Implicaciones biogeográficas. Rev. Espanola Micropaleontol. 41, 91-105.

Affolter, S., Häuselmann, A., Fleitmann, D., et al., 2019. Central Europe temperature constrained by speleothem fluid inclusion water isotopes over the past 14,000 years. Sci. Adv. 5, eaav3809.

Allué, E., Euba, I., 2008. Los datos antracológicos de la secuencia neolítica de El Mirador (Atapuerca, Burgos): un estudio sobre el medio vegetal y la explotación de las especies vegetales leñosas. In: Hernández-Pérez, M.S., Soler Díaz, J.A., López Padilla, J.A. (Eds.), IV Congreso de Neolítico Peninsular 2006. Museo Arqueológico de Alicante (MARQ), Alicante, pp. 345-352.

Alvisi, F., Dinelli, E., 2002. Evolution of sediment composition of the coastal Lake San Puoto (Latium, Italy) in the last two centuries. J. Limnol. 61, 15-26.

Anderson, N.J., 1995. Naturally eutrophic lakes: reality, myth or miopia. Trends Ecol. Evol. 10, 137-138.

Ariztegui, D., Anselmetti, F.S., Robbiani, J.-M., et al., 2010. Natural and humaninduced environmental change in southern Albania for the last 300 years constraints from the Lake Butrint sedimentary record. Global Planet. Change 7, $183-192$.

Berger, J.-F., Shennan, S., Woodbridge, J., et al., 2019. Holocene land cover and population dynamics in southern France. Holocene 29, 776-798.

Bringué, J.M., 2005. L'Edat moderna. In: Marugan, C.M., Rapalino, V. (Eds.), Història del Pallars. Dels orígens als nostres dies. Pagès Editors, Lleida, pp. 45-86.

Büntgen, U., Myglan, V.S., Charpentier, F., et al., 2016. Cooling and societal change during the late Antique little icea age from 536 to around 660 AD. Nat. Geosci. 9, 231-236.

Burjachs, F., 1996. La secuencia palinológica de La Cruz (Cuenca, España). In: RuizZapata, M.B. (Ed.), Estidous Palinológicos. Universidad de Alacalá, Alcalá de Henares, pp. 31-36.

Cabezudo, B., Recio, M., Sámches-Laulhé, J.M., et al., 1997. Atmospheric transportation of marihuana pollen from north Africa to the Southwest of Europe. Atmos. Environ. 31, 3323-3328.

Camps, J., Gonzalvo, I., Güell, J., et al., 1976. El lago de Montcortès, descripción de un ciclo annual. Oecol. Aquat. 2, 99-110.

Cañellas-Boltà, N., Rull, V., Vigo, J., et al., 2009. Modern pollen-vegetation relationships along an altitudinal transect in the central Pyrenees (south-western Europe. Holocene 19, 1185-1200.

Carreras, J., Vigo, J., Ferré, A. 2005-2006. Manual dels hàbitats de Catalunya, vols. vols. I-VIII. Departament de Medi Ambient i Habitatge, Generalitat de Catalunya, Barcelona.

Carrión, J.S., 2012. Paleoflora y Paleovegetación de la Penísnsula Ibérica e Islas Baleares: Plioceno-Cuaternario. Ministerio de Economía y Competitividad, Madrid.

Carrión, J.S., Andrade, A., Bennet, K.D., et al., 2001. Crossing forest thresholds: inertia and collapse in a Holocene sequence from south-Central Spain. Holocene 11, 635-653.

Carrión, J.S., Yll, E.I., Willis, K.J., et al., 2004. Holocene forest history of the eastern plateaux in the Segura mountains (Murcia, Southeastern Spain). Rev. Palaeobot. Palynol. 132, 219-236.

Catalan, J., Pérez-Obiol, R., Pla, S., 2000. Canvis climàtics a Aigüestortes durant els darrers 15.000 Anys. V J. Sobre Recerca al Parc Nacl. d'Aigüestortes I Estany de Sant Maurici, Espot 45-52.

Catalan, J., Pla, S., García, J., et al., 2009. Climate and $\mathrm{CO}_{2}$ saturation in an alpine lake througout the Holocene. Limnol. Oceanogr. 54, 2542-2552.

Catalan, J., Pèlachs, A., Gassiot, E., et al., 2013. Interacción entre clima y ocupación humana en la configuración del paisaje vegetal del Parque Nacional de Aigüestortes i Estany de Sant Maurici a lo largo de los últimos 15.000 años. Proyectos de Investigación en Parques Nacionales: 2009-2012. Org. Autón. Parques Nacl. 71-92. Madrid.
Clop, X., Faura, J.M., 1995. La Cabana de Perauba (Peracalç, Pallars Sobirà) i el megalitisme al Pallars. Revista d'Arqueologia de Ponent 5, 127-142.

Corella, J.P., Moreno, A., Morellón, M., et al., 2011a. Climate and human impact on a meromictic lake during the last 6,000 years (Montcortès Lake, Central Pyrenees, Spain). J. Paleolimnol. 46, 351-367.

Corella, J.P., El Amrani, A., Sigró, J., et al., 2011b. Recent evolution of Lake Arreo, northern Spain: influences of land use and climate change. J. Paleolimnol. 46, 469-485.

Corella, J.P., Brauer, A., Mangili, C., et al., 2012. The 1.5-ka varved record of Lake Montcortès (southern Pyrenees, NE Spain). Quat. Res. 78, 323-332.

Corella, J.P., Stefanova, V., El Anjoumi, A., et al., 2013. A 2500-year multi-proxy reconstruction of climate change and human activities in northern Spain: the Lake Arreo record. Palaeogeogr. Palaeoclimatol. Palaeoecol. 386, 555-568.

Corella, J.P., Benito, G., Rodriguez-Lloveras, X., et al., 2014. Annually-resolved lake record of extreme hydro-meteorological events since AD 1347 in NE Iberian Peninsula. Quat. Sci. Rev. 93, 77-90.

Corella, J.P., Valero-Garcés, B.L., Vicente-Serrano, S.M., et al., 2016. Three millennia of heavy rainfalls in Western Mediterranean: frequency, seasonality and atmospheric drivers. Sci. Rep. 6, 38206.

Corella, J.P., Benito, G. Wilhelm, B., et al., 2019. A millennium-long perspective of flood-related seasonal sediment yield in Mediterranean watersheds. Global Planet. Change 177, 127-140.

Cots, P., 2005. Els pobles de la prehistòria i l'antiguitat. In: Marugan, C.M., Rapalino, V. (Eds.), Història del Pallars. Dels orígens als nostres dies. Pagès Editors, Lleida, pp. 13-43.

Cunill, R., Soriano, J.M., Bal, M.C., et al., 2013. Holocene high-altitude vegetation dynamics in the Pyrenees: a pedoanthracology contribution to an interdisciplinary approach. Quat. Int. 289, 60-70.

de Bolós, O., 2001. Vegetació Dels Països Catalans. Aster, Barcelona.

Delgado, J.M., 1994. La indústria de la construcció naval catalana (1750-1850). Drassana 2, 34-39.

Dubois, H., Verkasalo, E., Claessens, H., 2020. Potential of Birch (Betula pendula Roth and B. pubescens Ehrh.) for forestry and forest-based industry sector within the changing climate and socio-economic context of western Europe. Forests 11, 336.

Ejarque, A., 2009. Génesis y Configuración Microregional de un Paisaje Cultural Pirenaico de Alta Montaña Durante el Holoceno: estudio Polínico y de Otros Indicadores Paleoambientales en el Valle del Madriu-Perafita-Claror (Andorra). PhD dissertation. Universitat Rovira i Virgili (Tarragona).

Ejarque, A., Julià, R., Riera, S., et al., 2009. Tracing the history of highland human management in the eastern pre-Pyrenees: an interdisciplinary palaeoenvironmental study at the Pradell fen, Spain. Holocene 19, 1241-1255.

Ejarque, A., Miras, Y., Riera, S., et al., 2010. Testing micro-regional variability in the Holocene shaping of high mountain cultural landscapes: a palaeoenvironmental case-study in the eastern Pyrenees. J. Archaeol. Sci. 37, $1468-1479$.

England, A., Eastwood, W.J., Roberts, C.N., et al., 2008. Historical landscape change in Cappadocia (central Turkey): a palaeoecological investigation of annually laminated sediments from Nar Lake. Holocene 18, 1229-1245.

Finsinger, W., Bigler, C., Krähenbühl, U., et al., 2006. Human impacts and eutrophication patterns during the past 200 years at Lago Grande di Avigliana (N. Italy). J. Paleolimnol. 36, 55-67.

Folch, R., Franquesa, E., Camarasa, J.M., 1984. Història natural dels Països Catalans. Veg. Encicl. Catalana 7 (Barcelona).

Franco-Múgica, F., García-Antón, M., 1994. Análisis polínico de una turbera en Rascafría (Madrid). In: de la Serna, I. (Ed.), Polen y esporas: contribución a su conocimiento. Serie informes, vol. 35, pp. 361-369.

Franco-Múgica, F., García-Antón, M., Maldonado Ruiz, J., et al., 2001a. The Holocene history of Pinus forests in the Spanish northern Meseta. Holocene 11, 343-358.

Franco-Múgica, F., García-Antón, M., Maldonado Ruiz, J., et al., 2001b. Evolución de la vegetación en el sector septentrional del Macizo de Ayllón (Sistema Central). Análisis polínico de la turbera de Pelagallinas. An. del Jardín Botánico Madr. 59, 113-124.

Fuentes, N., Carrión, J.S., Fernández, S., et al., 2007. Análisis polínico de los yacimientos arqueológicos Cerro del Alcázar de Baeza y Eras del Alcázar de úbeda (Jaén). An. Biol. 29, 85-93.

Garcés-Pastor, S., Cañellas-Boltà, N., Clavaguera, A., et al., 2016. Vegetation shifts, human impact and peat bog development in Bassa Nera pond (Central Pyrenees) during the last millennium. Holocene 27, 553-565.

Garcés-Pastor, S., Cañeellas-Boltà, N., Pèlachs, A., et al., 2017. Environmental history and vegetation dynamics in response to climate variations and human pressure during the Holocene in Bassa Nera, Central Pyrenees. Palaeogeogr. Palaeoclimatol. Palaeoecol. 479, 48-60.

García-Antón, M., Franco-Múgica, F., Maldonado Ruiz, J., et al., 1997. New data concerning the evolution of the vegetation in Lillo Pinewood (León, Spain) J. Biogeogr. 24, 929-934.

García-Ruiz, J.M., Tomás-Faci, G., Diarte-Blasco, P., et al., 2020. Transhumance and long-term deforestation in the subalpine belt of the central Spanish Pyrenees: an interdisciplinary approach. Catena 195, 104744.

Gil-Romera, G., García-Antón, M., Calleja, J.A., 2008. The late Holocene palaeoecological sequence of Serranía de las Villuercas (southern Meseta, western Spain). Veg. Hist. Archaeobotany 17, 653-666.

González-Sampériz, P., Aranbarri, J., Pérez-Sanz, A., et al., 2017. Environmental and climate change in the southern Central Pyrenees since the Last Glacial Maximum: a review from the lake records. Catena 149, 668-688. 
González-Sampériz, P., Montes, L., Aranbarri, J., et al., 2019. Escenarios, tiempo e indicadores paleoambientales para la identificación del Antropoceno en el paisaje vegetal del Pirineo central (NE Iberia). Cuadernos de Invest. Geogr. 45, 167-193.

Gribbin, J., Lamb, H.H., 1978. Climatic change in historical times. In: Gribbin, J. (Ed.), Climatic Change. Cambridge University Press, Cambridge, pp. 68-82.

Gutiérrez, F., Linares, R., Roqué, C., et al., 2012. Investigating gravitational grabens related to lateral spreading and evaporite dissolution subsidence by means of detailed mapping, trenching, and electrical resistivity tomography. Lithosphere 4, 331-353.

Halsall, G., 2008. Barbarian Migrations and the Roman West, 376-568. Cambridge Univ. Press, Cambridge.

Helama, S., Jones, P.D., Briffa, K.R., 2017. Dark Ages Cold Period: a literature review and directions for future research. Holocene 27, 1600-1606.

Jenny, J.-P., Koirala, S., Gregory-Eaves, I., et al., 2019. Human and climate global-scale imprint on sediment transfer during the Holocene proceedings of the national academy of Sciences USA, 116, 22972-22976.

Jones, M.D., Roberts, C.N., Leng, M.J., et al., 2006. A high-resolution late Holocene lake isotope record from Turkey and links to North Atlantic and monsoon climate. Geology 34, 361-364.

Juliá, R., Burjachs, F., Dasí, M.J., et al., 1998. Meromixis, origin and recent trophic evolution in the Spanish mountain lake La Cruz. Aquat. Sci. 60, 279-299.

Lami, A., Niessen, F., Guilizzoni, P., et al., 1994. Palaeolimnological studies of the eutrophication of volcanic Lake Albano (Central Italy). J. Paleolimnol. 10, $181-197$.

Lami, A., Guilizzoni, P., Ryves, D.B., et al., 1997. A Late Glacial and Holocene record of biological and environmental changes from the crater Lake Albano, central Italy: an interdisclinary European project (PALICLAS). Water, Air, Soil Pollut. 99, 601-613.

Langgut, D., Neumann, F.H., Stein, M., et al., 2014. Dead Sea pollen record and history of human activity in the judean highlands (Israel) from the intermediate bronze into the iron ages ( 2500-500 BCE). Palynology 38, 280-302.

Leunda, M., González-Sampériz, P., Gil-Romera, G., et al., 2017. The Late-Glacial and Holocene Marboré Lake sequence (2612 m a.s.l., Central Pyrenees, Spain): testing high altitude sites sensitivity to millennial scale vegetation and climate variability. Global Planet. Change 15, 214-231.

Lionello, P., 2012. The Climate of the Mediterranean Region. Elsevier, Amsterdam. Loidi, J., 2017. The Vegetation of the Iberian Peninsula. Springer (Cham).

López-Merino, L., López-Sáez, J.A., Alba Sánchez, F., et al., 2009. Estudio polínico de una laguna endorreica en Almenara de Adaja (Valladolid, Meseta Norte): cambios ambientales y actividad humana durante los últimos 2800 años. Rev. Espanola Micropaleontol. 41, 333-348.

López-Sáez, J.A., Blanco González, A., López-Merino, L., et al., 2009. Landscape and climatic changes during the end of the late Prehistory in the Amblés Valley (Ávila, Central Spain), from 1200 to 400 cal BC. Quat. Int. 200, 90-101.

Luzón, A., Pérez, A., Mayayo, M.J., et al., 2007. Holocene environmental changes in the Gallocanta lacustrine basin, Iberian range, NE Spain. Holocene 17, 1-15.

Madoz, P., 1845-1850. Diccionario geográfico-estadístico-histórico de España y sus posesiones de ultramar. Estudio Literario-Topográfico de P. Madoz y L. Sagasti, Madrid.

Mann, M.E., Zhang, Z., Rutherford, S., et al., 2009. Global signatures and dynamic origins of the little Ice age and the medieval climate anomaly. Science 326, 1256-1260.

Martín-Chivelet, J., Muñoz-García, M.B., Edwards, R.L., et al., 2011. Land surface temperature changes in Northern Iberia since $4000 \mathrm{yr}$ BP, based on $\delta^{13} \mathrm{C}$ of speleothems. Global Planet. Change 77, 1-12.

Martín-Puertas, C., Valero-Garcés, B.L., Mata, M.P., et al., 2008. Arid and humid phases in the southern Spain during the last 4000 years: the Zóñar lake record, Córdoba. Holocene 18, 907-921.

Martín-Puertas, C., Valero-Garcés, B.L., Brauer, A., et al., 2009. The Iberian-Roman Humid Period (2600-1600 cal yr BP) in the Zoñar lake varved record (Andalucía, southern Spain). Quat. Res. 71, 108-120.

Marugan, C.M., Oliver, J., 2005. El Pallars medieval. In: Marugan, C.M., Rapalino, V. (Eds.), Història del Pallars. Dels Orígens als Nostres Dies. Pagès Editors, Llleida, pp. $45-86$.

Marugan, C.M., Rapalino, V., 2005. In: Història del Pallars. Dels Orígens als Nostres Díes. Pagès Editors, Lleida.

Mercadé, A., Vigo, J., Rull, V., et al., 2013. Vegetation and landscape around Lake Montcortès (Catalan pre-Pyrenees) as a tool for palaeoecological studies of lake sediments. Colectanea Botan. 32, 87-101.

Mercuri, A.M., Accorsi, C.A., Mazzanti, M.B., 2002. The long history of Cannabis and its cultivation by the Romans in central Italy, shown by pollen records from Lago Albano and Lago di Nemi. Veg. Hist. Archaeobotany 11, 263-276.

Migowski, C., Agnon, A., Bookman, R., et al., 2004. Recurrence pattern of Holocene earthquakes along the Dead Sea transform revealed by varve-counting and radiocarbon dating of lacustrine sediments. Earth Planet Sci. Lett. 222, 301-314.

Miras, Y., Ejarque, A., Riera, S., et al., 2007. Dynamique holocène de la végétation et occupation des Pyrénées andorranes depuis le Néolithique ancien, d'après l'analyse pollinique de la tourbière de Bosc dels Estanyons (2180 m, Vall de Madriu, Andorre). Comptes Rendus Palevol 6, 291-300.

Miras, Y., Ejarque, A., Riera, S., et al., 2015. Andorran high Pyrenees (perafita valley, Andorra): serra mitjana fen. Grana 54, 313-316.

Modamio, X., Pérez, V., Samarra, F., 1988. Limnología del lago de Montcortès (ciclo 1978-1979). Oecol. Aquat. 9, 9-17.

Monatti, J.-P., Thiebault, S., 2016. The Mediterranean Region under Climate Change.
IRD Éditions, Marseille.

Montoya, E., Rull, V., Vegas-Vilarrúbia, T., et al., 2018. Grazing activities in the southern central Pyrenees during the last millennium as deduced from the nonpollen palynomorphs (NPP) record of Lake Montcortès. Rev. Palaeobot. Palynol. 254, 8-19.

Montserrat-Martí, J.M., 1992. Evolución Glaciar y Postglaciar del Clima y la Vegetación en la Vertiente Sur del Pirineo: estudio Palinológico. Monogr. Inst. Pirenaico Ecol. (CSIC) 6, 1-147.

Morellón, M., Anselmetti, F.S., Ariztegui, D. et al., 2016. Human-climate interactions in the central Mediterranean region during the last millennia: the laminated record of Lake Butrint (Albania). Quat. Sci. Rev. 136, 134-152.

Muñoz-Sobrino, C., Ramil-Rego, P., Rodríguez-Guitián, M.A., 1997. Upland vegetation in the north-west Iberian peninsula after the last glaciation: forest history and deforestation dynamics. Veg. Hist. Archaeobotany 6, 215-233.

Muñoz-Sobrino, C., Ramil-Rego, P., Gómez-Orellana, L., 2004. Vegetation of the Lago de Sanabria area (NW Iberia) since the end of the Pleistocene: a palaeoecological reconstruction on the basis of two new pollen sequences. Veg. Hist. Archaeobotany 13, 1-22.

Neumann, F.H., Kagan, E.J., Schwab, M.J., et al., 2007. Palynology, sedimentology and palaeoecology of the late Holocene Dead Sea. Quat. Sci. Rev. 26, 1476-1498.

Ojala, A.E., Saarinen, T., Salonen, V.P., 2000. Preconditions for the formation of annually laminated lake sediments in southern and central Finland. Boreal Envorn. Res. 5, 143-255.

O'Sullivan, P.E., 1983. Annually-laminated lake sediments and the study of Quaternary environmental changes - a review. Quat. Sci. Rev. 43, 45-60.

Panyella, A., 1944. La Pleta de Compte en Peramea. Ampurias 6, 69-86.

Pèlachs, A., Soriano, J.M., Nadal, J., et al., 2007. Holocene environmental history and human impact in the Pyrenees. Contrib. Sci. (Los Angel.) 3, 421-429.

Pèlachs, A., Pérez-Obiol, R., Ninyerola, M., et al., 2009. Landscape dynamics of Abies and Fagus in the southern Pyrenees during the last 2200 years as a result of anthropogenic impacts. Rev. Palaeobot. Palynol. 156, 337-349.

Peña-Chocarro, L., Pérez-Jordà, G., Alonso, N., et al., 2019. Roman and medieval crops in the Iberian Peninsula: a first overview of seeds and fruits from archaeological sites. Quat. Int. 499, 49-66.

Peñalba, M.C., 1994. The history of the Holocene vegetation in northern Spain from pollen analysis. J. Ecol. 82, 815-832.

Pérez-Díaz, S., López-Sáez, J.A., Núñez, S., 2018. Early farmers, megalithic builders and the shaping of the cultural landscapes during the Holocene in the Northern Iberian Mountains. A palaeoenvironmental perspective. J. Archaeol. Sci. 18, 463-474.

Pérez-Sanz, A., González-Sampériz, P., Moreno, A., et al., 2013. Holocene climate variability, vegetation dynamics and fire regime in the central Pyrenees: the Basa de la Mora sequence (NE Spain). Quat. Sci. Rev. 73, 149-169.

Piera, M., 2013. El Pla de la Guineu (Gerri de la Sal): primeres evidències d'explotació de la sal en època del bronze. Primeres Jornades d'Arqueologia I Paleontologia del Pirineu i Aran, Coll de Nargó-La Seu d'Urgell, pp. 52-57. November 2013.

Piera, M., Pancorbo, A., Garcés, I., et al., 2013. Els assentaments de les edats del bronze, ibèrica i romana dels Llirians del Mas i les Torres (Salàs de Pallars, Pallars Jussà). Revista d'Arqueologia de Ponent 23, 163-200.

Pla, S., Catalan, J., 2005. Chrysophyte cysts from lake sediments reveal the submillennial winter/spring climate variability in the northwestern Mediterranean region throughout the Holocene. Clim. Dynam. 24, 263-278.

Riera, S., Wansard, G., Julià, R., 2004. 2000-year environmental history of a karstic lake in the Mediterranean Pre-Pyrenees: the Estanya lakes (Spain). Catena 55, $293-324$.

Riera, S., López-Sáez, J.A., Julià, R., 2006. Lake responses to historical land use changes in northern Spain: the contribution of non-pollen palynomorphs in a multiproxy study. Rev. Palaeobot. Palynol. 141, 127-137.

Roberts, N., Allcock, S.L., Arnaud, F., et al., 2016. A tale of two lakes: a multiproxy comparison of Lateglacial and Holocene environmental change in Cappadocia, Turkey. J. Quat. Sci. 31, 348-362.

Romero-Viana, L., Juliá, R., Camacho, A., et al., 2008. Climate signal in varve thickness: lake La Cruz (Spain), a case study. J. Paleolimnol. 40, 703-714.

Ruiz-Zapata, M.B., Gómez González, C., Gil-García, M.J., et al., 2008. Comparación de las secuencias polínicas del Holoceno reciente del yacimiento arqueopaleontológico de El Calvero de la Higuera (Pinilla del Valle, Madrid) y de la turbera de Rascafría (Madrid). Geotemas 10, 1484-1486.

Rull, V., Vegas-Vilarrúbia, T., 2014. Preliminary report on a mid-19 ${ }^{\text {th }}$ century Cannabis pollen peak in NE Spain: historical context and potential chronological significance. Holocene 24, 1378-1383.

Rull, V., Vegas-Vilarrúbia, T., 2015. Crops and weeds from the Estany de Montcortès catchment, central Pyrenees, during the last millennium: a comparison of palynological and historical records. Veg. Hist. Archaeobotany 24, 699-710.

Rull, V., Vegas-Vilarrúbia, T., 2021. A spatiotemporal gradient in the anthropization of Pyrenean landscapes. Preliminary report. Quat. Sci. Rev. 258, 106909.

Rull, V., González-Sampériz, P., Corella, J.P., et al., 2011. Vegetation changes in the southern Pyrenean flank during the last millennium in relation to climate and human activities: the Montcortès lacustrine record. J. Paleolimnol. 46, 387-404.

Rull, V., Trapote, M.C., Safont, E., et al., 2017. Seasonal patterns of pollen sedimentation in Lake Montcortès (Central Pyrenees) and potential applications to highresolution paleoecology: a 2-year pilot study. J. Paleolimnol. 57, 96-108.

Rull, V., Vegas-Vilarrúbia, T. Corella, J.P., et al., 2021. Bronze Age to Medieval vegetation dynamics and landscape anthropization in the southern-central Pyrenees. Palaeogeogr. Palaeoclimatol. Palaeoecol. 571, 110392. 
Sabartés, J.M., 1993. L’Èxode Pallarès. Crisi demogràfica i devallada poblacional als Pallars i a l'Alta Ribagorça (1857-1991) (Garsineu Edicions, Tremp).

Sanz, V. 1995. D'artesans a proletaris: la manufactura del cànem a Castelló, 1732-1843. Publ. Diputació de Castelló, (Castelló).

Scussolini, P., Vegas-Vilarrúbia, T., Rull, V., et al., 2011. Middle and Late Holocene climate change and human impact inferred from diatoms, algae and aquatic macrophyte pollen in sediments from Lake Montcortès (NE Iberian Peninsula). J. Paleolimnol. 46, 369-385.

Simon, M., Vicente, O., 2002. Noves dades sobre el poblament de finals del III mil·leni Cal BC a la Serra Magdalena (Pallars Sobirà, Lleida. XII Col·loqui Int. d'Arqueol. Puigcerdà, Puigcerdà 2002, 207-218.

Smittenberg, R.H., Baas, M., Schouten, S., et al., 2005. The demise of the alga Botryococcus braunii from a Norwegian fjord was due to early eutrophication. Holocene 15, 133-140.

Steffens, L., Fuller, D., Boivin, N., et al., 2019. Archaeological assessment reveals Earth's early transformation thorugh land use. Science 365, 897-902.

Trapote, M.C., Vegas-Vilarrúbia, T., López, P., et al., 2018a. Modern sedimentary analogues and integrated monitoring to understand varva formation in the
Mediterranean Lake Montcortès (Central Pyrenees, Spain). Palaeogeogr. Palaeoclimatol. Palaeoecol. 496, 292-304.

Trapote, M.C., Rull, V., Giralt, S., et al., 2018b. High-resolution (sub-decadal) pollen analysis of varved sediments from Lake Montcortès (souther Pyrenean flank): a fine-tuned record of landscape dynamics and human impact during the last 500 years. Rev. Palaeobot. Palynol. 259, 207-222.

Veal, R., 2017. The politics and economics of ancient forests: timber and fuel as levers of greco-Roman control. In: Derron, P. (Ed.), Economie et inégalité: Ressources, échanges et pouvoir dans l'Antiquité classique. Hardt Foundation, Geneva, pp. 317-367.

Vegas-Vilarrúbia, T., Corella, J.P., Pérez-Zanón, N., et al., 2018. Historical shifts in oxygenation regime as recorded in the laminated sediments of Lake Montcortès (Central Pyrenees) support hypoxia as a continental-scale phenomenon. Sci. Total Envrion. 612, 1577-1592.

Vigo, J., Ninot, J., 1987. Los Pirineos. In: Peinado, M., Rivas-Martínez, F. (Eds.), La Vegetación de españa. Universidad de Alcalá de Henares, Madrid, pp. 349-384.

Zolitschka, B., Francus, P., Ojala, A.E.K., et al., 2015. Varves in lake sediments-a review. Quat. Sci. Rev. 117, 1-41. 